\title{
EL FENÓMENO DE LOS CRISTIANOS NUEVOS EN IBEROAMÉRICA
}

\author{
Eva Alexandra Uchmany \\ Universidad Nacional Autónoma de México \\ Investigadora Nacional \\ Premio Universidad Nacional \\ en Investigación en Ciencias Sociales 2007 \\ México \\ evau@prodigy.net.mx
}

\begin{abstract}
RESUMEN
El artículo trata de las persecuciones religiosas en la época goda en la Península Ibérica, se menciona la conquista árabe que liberó a los judíos de la esclavitud que les preparaba el gobiemo godo. Su liberación en la época árabe y una vez más la extensión del antisemitismo en la España cristiana, que se inició en la época moderna en la que la emergente burguesía se negaba a compartir con los judios las posibilidades que la modernidad les ofrecía. Las agresiones y ataques a las juderías se envolvían en un manto de una guerra santa o cruzada contra herejes asesinos de Dios. La introducción del Santo Oficio de la Inquisición por los Reyes Católicos y sus consecuencias tanto en España y Portugal como en las colonias americanas. Así mismo se nartan vidas de algunos cristianos nuevos y sus experiencias bajo la vigilancia del Santo Oficio que les cerraba todas las posibilidades para su subsistencia. A su vez se señalan casos individuales de grandes funcionarios de origen hebreo y su caída y aniquilación de sus nombres en los siglos XVI y XVII por el Santo Oficio.
\end{abstract}

PaLABRAs Clave: historia colonial, inquisición, judios, cristianos nuevos.

\begin{abstract}
The article deals with the religious persecution in the Iberian Peninsula during the SpanishGothic government before the Arab Conquest. Some years later, after the Spanish Reconquest the formation of new religious order in Spain tried to made new converse in Spain and other European countries. The new anti-Jewish spirits established the formal Holy Office of the Inquisition in Spain in 1478, by the Catholic Kings, Isabel and Fernando. Finally they ordered the expulsion of Jews and other heretics from their Monarchy. But this act did not made Spain free of Jews. Between the first conquerors and settlers always has been someone who was from Jewish origin. It is known that many Jews came to New World with Columbus, suspicious by himself to be from Jews origin. Many arrived with other expeditions or as individual traders to look for a new life far from Europe. But the situation has been different because the Primitive Inquisition was established in New Spain very early, with the arrival of the Dominican Order. Their first victim was the conqueror Hernando Alonso, who was publicly burned in 1528 . In some other islands the Dominican Fryers began their activities already in 1523. The formal establishment of the Holy Office of the Inquisition in Spanish America was in 1571 and has been abolished in 1820 .
\end{abstract}


Key Words: Colonial History, Inquisition, Jews: New Christians, From Medieval to Modern Times.

En la ciudad andaluza de Elvira, situada cerca de Granada, se reunieron en el año 309, diecinueve obispos y veintiséis presbíteros, la mayoria era originaria del sur de la península ibérica, para discutir y legislar las reglas que deberían regir a sus feligreses. Una notable mayoría de los cánones eran prohibitivos, ya que se trataba el tema de las relaciones sexuales que debían regir a sus comunidades. Entre otros se prohibía (canon XVI) el casamiento de un hombre cristiano con una mujer judía y viceversa. Se exigia que la mujer o el hombre judío se conviertan al cristianismo, ley que obligaba tanto a paganos como a personas provenientes de otros grupos religiosos'. Así mismo se ordenó el celibato a los clérigos (canon XIII), que se discutía en varias ocasiones por su importancia. En el caso de que el hombre no pudo controlar sus instintos no se le perdonaba, "ni al fin". Esto es, se le negaba la comunión incluso en el lecho de su muerte. En cambio la mujer podía obtener un perdón y recibir comunión después de una rigurosa y larga penitencia.

De aquí que la naciente Iglesia buscaba romper y rompió todos los lazos sociales entre los judíos y sus feligreses, como por ejemplo, prohibir una antigua costumbre "que los rabinos bendecían los campos y viñedos de sus vecinos y de otros, así como sus cosechas" (canon XLIX). Incluso las buenas relaciones sociales que reinaban entre la población romana, incluyendo a los cristianos, con los judios que llegaban a reunirse en fiestas cívicas y sociales, en las que comían y bebían juntos, fueron estrictamente prohibidas por los cánones de Elvira y de los siguientes concilios. El dominio sobre la sexualidad del clero le dio no tan solo prestigio en el mundo antiguo, sino un gran poder sobre todos aquellos que con el tiempo engrosaban las filas cristianas por su voluntad o por la fuerza. A su vez, no tan solo dividió socialmente a los cristianos de los judíos, sino que provocó hacia ellos un odio social y político a lo largo de los últimos diecisiete siglos que causaron millones de torturas, asesinatos y, entre otros, el reciente Holocausto.

El asentamiento judío en la península ibérica fue uno de los más antiguos y prósperos en sus primeras fases, incluso después de la conquista de los visigodos. El gobierno fue favorable con las comunidades hebreas durante un largo tiempo. Ellos ganaban su vida con dignidad y no fueron molestados por su religión, viviendo de acuerdo con sus leyes religiosas a lo largo de muchos siglos. Sin embargo, en 586, la situación judía se había modificado, ya que se inició una época de disturbios, cambiando los gobernantes visigodos de religión: del arrianismo al catolicismo. El rey Recaredo comenzó a gobernar en 586, y un año más tarde, inspirado por el Papa Gregorio I (590-604), aceptó el bautismo católico, convirtiéndose en 587. De inmediato cambió su actitud

1 Samuel Laeuchli, Power and sexuality, the emergence of canon law at the synod of Elvira, Philadelphia, Temple University Press, 1972, pp. 5-7. 
hacia los judíos, y comenzó a perseguirlos: los obligó a guardar el domingo y les prohibió cantar salmos durante sus entierros ${ }^{2}$.

Los siguientes monarcas siguieron sus pasos. En 612 subió al trono el rey Sisebuto que gobernó entre 612 a 621 . Sisebuto trató de establecer notables diferencias entre la población cristiana y los judíos. Además, quería convertirlos al cristianismo o debian abandonar el reino. De inmediato los judíos comenzaron a fugarse de España y se asentaron en los territorios de la antigua nobleza romana, y también huyeron a Galia y al norte de África. La mayoría logró abandonar el reino. Cabe mencionar que el antijudaísmo se decidía en los concilios de la Iglesia encabezados por entonces ya por los mismos reyes.

En efecto, los concilios se convirtieron en el cuerpo legislativo del reino. En particular fue importante el Cuarto Concilio reunido en Toledo en 633, presidido por el rey Sisenando, quien gobernó entre 633 y 636 . En este concilio se discutió una vez más el problema judío y se decidió limitarlos aun más de lo que ya estaban. La nueva ley les prohibía fungir como testigos en juicios entre judíos y católicos. Además se les prohibía tener cargos públicos para no causar injusticia a los cristianos. He aqui que, por vez primera se prohibió a los judios, y a sus sucesores, ejercer cargos con jurisdicción sobre los cristianos. Esta ley fue años más tarde revivida por Juan II de Castilla en 1406-1454. Pocos años más tarde, el rey Ervigio intentó bautizar a todos los judíos del reino. Ante este peligro, miles huyeron y miles fueron bautizados. Su sucesor Egica, que gobernó entre 687 a 702 , organizó el 10 de noviembre de 694 el Concilio número XVII. De inmediato confiscó los bienes de los judíos y entregó sus hijos de siete años cumplidos a familias cristianas para que los reeducasen, y sometió a sus mujeres a esclavitud perpetua. Por fortuna esas decisiones totalitarias no fueron siempre ejecutadas. Aunque en vista de esta legislación, miles de judios abandonaron de nuevo España.

Desde 711, los godos estaban peleando entre sí por el poder. Después de la muerte del rey Witiza, sus herederos fueron apartados del gobierno, pues la nobleza influenciada por el clero, que lo detestaba, coronó al conde Rodrigo, quien fue muerto dos años más tarde, al iniciarse la conquista árabe. Por su parte la casa de los Witiza, sintiéndose traicionada por los suyos, en unión con el gobernador bizantino de Ceuta, don Julián, quien después de la derrota de su imperio quedó atrapado en aquellas partes, también buscaba la protección árabe, les ofrecieron la ayuda necesaria para conquistar a España. En 713, Tarik ibn Zayid, con 11.000 mil hombres, penetraron a Córdova y desde allí comenzaron la conquista de España. Poco tiempo después, Musa ibn Nusair, con 18.000 mil hombres, se introdujo del lado opuesto. Los hombres de Witiza, que buscaron su recompensa, -por lo menos un importante cargo público-, se unieron desde un principio a los invasores junto con los judíos esclavizados. Por su parte los señores godos no tenían posibilidad alguna de ganar. El pueblo, especialmente los campesinos, estaban esclavizados por sus señores que les quitaban sus tierras y los dejaban casi sin medios para subsistir. De aquí que los campesinos del reino, aunque fueron llamados por sus señores a los campos de batalla, no tenian

2 Eliyahu Ashtor, The Jews of Moslem Spain, vol. I, Philadelphia, The Jewish Publication Society of America, 1973. 
incentivo alguno para defenderlos. En definitiva, en aquellas circunstancias las masas carecian de interés en la existencia de su tiránico gobierno. En esas circunstancias, el reino visigodo iba a colapsar en cualquier momento. Además, ese reino estaba tan mal administrado y a su vez era tan corrupto, que cualquier enemigo que quisiese atacarlo podria hacerlo sin ningún esfuerzo. Al mismo tiempo, el imperio árabe musulmán llegó a una situación de fuerza y esplendor que nunca había conocido y, por tanto, la conquista no se hizo esperar.

Los judíos que vivían en la península a lo largo de cientos de años, mucho antes de la conquista goda, eran campesinos y artesanos cuya existencia dependia mayormente de la agricultura. Por tanto sabian defender sus vidas y propiedades usando la fuerza, ya que de ello dependía su existencia. Las campañas de conquista llevadas a cabo por Táriq lbn Ziyad y Músá Ibn Nusair atravesaron el territorio judío. En Toledo proclamaron solemnemente la anexión de España al Califato árabe. Además, cuando planeaban nuevos ataques y campañas al norte de España, aparecieron de repente los mensajeros del califa y llamaron a Músá Ibn Nusair hacia el oriente. Marchó con grandes honores, pero al arribar a Damasco fue puesto en prisión hasta su muerte.

Dejó a su hijo Abdal'aziz como gobernador de España. Al tratar Abdal'aziz de reconciliar a los cristianos con los musulmanes, fue asesinado por su propia gente, ávida de conquistas y botines. Sin duda, las contradicciones entre las tropas de las diversas tribus árabes significaron la tragedia del Califato. Finalmente establecido el Califato, tuvo una actitud sumamente tolerante hacia los judíos y también hacia los visigodos.

Los nuevos gobernadores no sabian administrar muy bien lo conquistado y necesitaban ayuda de los mismos judíos y cristianos. Esta fue la situación del dominio árabe también en otros países. Por su parte la nobleza española abandonó sus lugares y sus propiedades y huyó al norte. Sus posesiones fueron repartidas entre los musulmanes. Finalmente, también los judíos respiraron por gozar de una absoluta libertad religiosa. Y cuando la noticia llegó al norte de África, miles y miles de hebreos, que había huido de la España visigoda, regresaban a su antigua tierra: a España. También la situación entre los musulmanes y los cristianos se volvió cordial.

Para no entrar en detalles acerca de la vida de los judíos a lo largo de la España árabe y medieval castellana, intentaremos analizar su situación después de la reconquista española, en la que su estatus comenzó a deteriorarse paulatinamente. Cabe mencionar que los tiempos habian cambiado, y la emergente burguesía desarrolló una nueva actitud hacia los judios, por lo general habitantes, en su mayoria, de ciudades. De aquí que las fricciones sociales y religiosas entre esos grupos se agudizaron a lo largo del siglo XIV. En 1391, culminaron en salvajes ataques a las juderías andaluzas. Luego se expandieron casi por todo el reino y tuvieron ecos en la vecina Portugal. La intolerancia religiosa fomentada por frailes celosos, hijos de la emergente burguesía, personificada en el dominico catalán Vicente Ferrer, inspiraron al arcediano de Ecija, Ferrand Martínez, atacar a las aljamas de la región. La turba que lo secundaba, y que se hizo llamar "matadores de judíos", masacró solamente en Sevilla y sus alrededores a más de 4.000 almas. Según 
testigos oculares, el número de hebreos que, impulsados por el terror aceptaron el bautismo a cambio de su vida, superó en gran número a los muertos ${ }^{3}$.

Sin embargo el escoger la pila bautismal en lugar del martirio era un fenómeno nuevo en el judaísmo europeo. Durante el movimiento de las Cruzadas, el primer blanco de los caballeros y de las hordas que los seguian eran las juderías. Los más violentos ataques sucedieron a lo largo de la Primera Cruzada que se inició en 1096. Durante su marcha, los cruzados se detenían en varias juderias en Francia, en las situadas a lo largo del Rin y en las diseminadas a las orillas del Danubio. Después de una breve prédica, los cruzados exhortaban a los judios a bautizarse. Pero éstos preferían el martirio a la conversión. Más aun, ellos mismos inmolaban a sus hijos, por lo general con el largo cuchillo destinado a la matanza de animales, afilado previamente, y luego se lo clavaban en su propio vientre para santificar así, con sus propias vidas, Su Santo Nombre. Las crónicas y otros testimonios mencionan a la heroica madre Raquel, que de este modo sacrificó a sus hijos diciéndoles, “...no temáis, pronto estaremos sentados en el Jardín del Edén gozando de su luz" . De aquí que los bautismos masivos de los hebreos españoles eran un indicador de que los tiempos habían cambiado: los aires de la modernidad trajeron consigo una nueva actitud hacia la vida y hacia la religiosidad en sí.

Las continuas persecuciones y la violencia que se extendió por toda la España a lo largo del siglo XV redujeron las aljamas a menos de la mitad de su población. Muchas desaparecieron por completo del mapa de la península. Las agresiones contra los judíos culminaron con su expulsión en 1492, llevada a cabo un día antes de que Cristóbal Colón zarpase con sus tres carabelas hacia un destino desconocido. El mismo Colón se refiere a este hecho con las siguientes palabras: "Así que después de haber echado fuera todos los judíos de todos vuestros reinos y señorios, en el mismo mes de enero mandaron vuestras altezas a mí, que con armada suficiente me fuese a las dichas partidas de Indias"s.

Los sucesivos ataques a las juderías producían más conversos que la sociedad española estaba preparada para absorber. Varios historiadores calculan que a la hora de la expulsión se quedaron en España alrededor de 100.000 judíos. Otros $90.000^{6}$ a 100.000 , fueron aceptados temporalmente en Portugal a cambio de 8 escudos por persona, por el rey don Emanuel. Otros 100.000 a 200.000 se esparcieron entre el norte de Africa y los Balcanes. Cabe mencionar, que los números no se basan en acuerdos entre historiadores sino en estimaciones. Por su parte los

3 Luis Suárez, La expulsión de los judios de España, MAPFRE, Madrid, 1992, p. 190

4 Shlomo Eidelberg, traductor and editor, The Jews and the Crusaders. The Hebrew Chronicles of the First and Second Crusades, The University of Wisconsin Press; Iván G. Marcus, "From Politics to Martyrdom: Shifting Paradigms in the Hebrew narratives of the 1096 Crusade riots", en Jeremy Cohen, editor, Essential Papars on Judaism and Christianity in Conftict; From Late Antiquity to the Reformation. New York University Press, 1991, pp. 469-483.

s Colón, Cristóbal, Los Cuatro Viajes del Almirante y su Testamento. Edición y Prólogo de Ignacio B. Anzoảtegui, $4^{3}$ edición, Espasa Calpe, Madrid, 1964. Colección Austral, p. 16

6 Discusiones entre varios autores que no se pusieron aún de acuerdo. 
recién bautizados tampoco eran bienvenidos en España, ya que aun antes de la mitad del siglo XV se acuñaron términos como cristiano viejo y nuevo, que indicaban segregación y desigualdad.

En el año 1449 aparecieron los prototipos de los Estatutos de Limpieza de Sangre. De inmediato, varias fundaciones privadas como el Colegio de San Bartolomé de Salamanca, cofradías de artesanos y otras instancias excluían a los conversos y a sus descendientes de su seno. Mayor resonancia tuvo el Estatuto del Consejo de Toledo, ideado por el Alcalde Mayor, Sarmiento, cristiano viejo y enemigo mortal de los cristianos nuevos, a los que excluía de todos los cargos y oficios de la ciudad. Esta actitud indignó a la Santa Sede. El Papa Nicolás V expidió casi de inmediato, el 24 de septiembre del mismo año, la bula Humani Generis que prohibia, con pena de excomunión mayor, cualquier discriminación social y económica contra los neófitos y sus descendientes? . Pero la sociedad cristiana vieja, que buscaba el modo de eliminar la competencia económico-social y, en particular, la de los beneficios eclesiásticos, desobedeció a la Santa Sede. En definitiva, las sociedades castellana, aragonesa, valenciana, lusitana y otras, que lucharon a lo largo de los siglos para sacar a los judíos "de sus errores y supersticiones", y pugnaban para conducirlos a la "religión verdadera", cuando esto sucedió, por persuasión o por coacción, se negaron a aceptarlos como iguales tanto en la sociedad como en el seno de la Iglesia.

Las ultimas décadas del siglo XV, caracterizadas por la centralización del poder en manos de la Corona, personificada por los Reyes Católicos, depararon a los judíos la expulsión y a los conversos y cristianos nuevos el Tribunal del Santo Oficio de la Inquisición, fundado en 1481. Por su parte, el Rey Católico, quien consideraba la religión como la razón unificadora del Estado, usó el Tribunal para extender el brazo de la Corona a todos los rincones de sus dominios. Y, aunque elevó a muchos conversos y cristianos nuevos a los más altos rangos de la burocracia civil y eclesiástica, tanto en España como en sus dominios allende el mar, perseguía a los otros.

\section{CRISTIANOS NUEVOS DE ORIGEN ESPAÑOL EN EL CUARTO CONTINENTE}

Desde su llegada a España, Cristóbal Colón se relacionaba, entre otros, con un número de judíos y cristianos nuevos que apoyaban su proyecto. Del judío Abraham Zacuto, que aplicaba las matemáticas a la náutica, obtuvo una copia de su Almanaque Perpetuo y también un astrolabio, que llevó consigo en el Primer Viaje. El cristiano nuevo Luis de Santángel, contador mayor del

7 Antonio Domínguez Ortiz, La clase social de los conversos en Castilla en la Edad Moderna, Introducción por Francisco Márquez Villanueva, semblanza del autor por Luis J. Coronas, Universidad de Granada, 1991, p. 3.

\$ Muy pocos estudiosos mencionan al matemático y astrónomo salmantino Abraham Zacuto, autor del Hakhibur Hagadol, traducido al latín por su discípulo Joseph Vecinho, astrónomo de la Corona de Portugal. Además, Zacuto construyó para el histórico viaje de Vasco da Gama un astrolabio que en los mares del Sur le permitió prescindir de la estrella Polar y ubicarse midiendo la altura y la declinación del Sol. Fernando Magallanes y sus capitanes también llevaban consigo el astrolabio y las tablas del astrónomo, a las que hicieron algunas correceiones en el hemisferio Sur. Pocos años más tarde, después de que Fernando expidió la ley que obligaba a todos los judios a convertirse al cristianismo, Abraham Zacuto huyó a Turquía. También 
reino de Aragón", persuadió a la Reina Católica para que aceptase el proyecto colombino, desembolsando dieciséis mil ducados para financiarlo. Gabriel Sảnchez, tesorero de Aragón emparentado con Santángel, también favoreció a Colón. De aquí que el Almirante dirigió las primeras noticias del Cuarto Continente, escritas en su viaje de regreso, a Luis de Santángel y al tesorero Gabriel Sánchez, confundiendo el nombre del último con otro arcángel, llamándole Rafael. Ambas misivas son idénticas en su contenido.

Gabriel, después de leer las primeras noticias del Mundo Nuevo, las envió de inmediato a otro primo suyo, el aragonés Leonardo Coscón en Italia. Coscón tradujo las Noticias al latín, y luego fueron publicadas por el hermano de Gabriel, Juan de Pedro Sánchez, en 1493, en Roma. Tanto Leonardo como Juan de Pedro participaron en el asesinato del inquisidor Pedro de Arbués, en compañía de otros cristianos nuevos de Aragón, y vivian refugiados en Italia. Esta primera descripción de las islas Antillas y de sus habitantes vio nueve ediciones antes de finalizar el siglo $\mathrm{XV}^{10}$.

Varios cristianos nuevos se embarcaron en el Primer Viaje de Colón. Entre ellos se hallaba el recién bautizado Luis de Torres, natural de Murcia, que sabía hebreo, caldeo y algo de árabe. Él junto con Rodrigo de Jerez, también cristiano nuevo, iniciaron la exploración de la primera isla que se descubrió, llamada por los naturales Guanahaní. En vista de que Colón creía que habia anclado en algún lugar del Océano Índico, Torres se dirigió a los atónitos y desnudos indígenas, concentrados en la playa, en hebreo", luego en arameo y finalmente en árabe, lenguas inteligibles en el Lejano Oriente. Así que las primeras palabras pronunciadas por un hombre blanco en el Cuarto Continente fueron en hebreo. Además, a bordo de los tres barcos estaban Marco, médico de la expedición, y el apotecario Maestre Bernal, penitenciado en 1490 por judaizante ${ }^{12}$, y quien acompañó a Colón también en el Cuarto y último viaje. En todas las expediciones de Colón estaban presentes uno que otro cristiano nuevo. Asimismo participaron en la Conquista de México, en la del Perú y en otras, como soldados, escribanos, contadores, oficiales reales, pobladores, mercaderes y otros. Una notable mayoría fue bautizada en años

cabe mencionar que Zacuto fue el único judío que en la última década del siglo XV fue invitado a dictar una cátedra de matemáticas y astrologia en la Universidad de Salamanea. Véase al respecto en Francisco Cantera Burgos, Abraham Zacut, siglo XV, M. Aguilar, Madrid [s/a, c. 1950]. En 1513, Zacuto se incorporo a una de las escuelas talmúdicas de gran prestigio en Jerusalén. Véase en Abraham David, To Come to the Land. Immigration and Settlement in Sixteenth-Century Eretz-lsrael, The University of Alabama Press, Toscaloosa \& London, 1999.

"Véase al respecto en José Amador de los Ríos, Historia social, politica y religiosa de los judios de España y Portugal, Aguilar, Madrid, 1960, p. 769, y la nota 3 en la misma página, que indica que este Luis de Santángel fue penitenciado por el Santo Oficio un año antes de haber otorgado este préstamo a la Corona. José Amador de los Rios, Historia social, politica y religiosa de los judios de España y Portugal, Madrid, Aguilar, 1960 (Sección Cultura e Historia) pp. 690-700.

1 Fray Bartolomé de las Casas, Historia de las Indias, Estudio preliminar por Lewis Hanke, Fondo de Cultura Económica (en adelante FCE), México, 1965, vol. 1, p. 227.

12 Antonio Dominguez Ortiz, Los judeoconversos en España y América, Madrid, Ediciones Istmo, 1971, p. 129. 
previos a la expulsión y, por tanto, estaba ya asimilada al modo de vida de los cristianos viejos, aunque algunos aún recordaban formas e ideas de su religión ancestral. Sin embargo, todos trataban de borrar su origen hebreo, olvidar sus raices y fusionarse con la población cristiana vieja, que no tan solo fue incitada a odiarlos sino que se negaba compartir con ellos los beneficios que ofrecía la empresa americana.

En 1501, don Fernando declaró que ninguna persona penitenciada por el Tribunal de la Inquisición, ni sus hijos o nietos podían tener oficio alguno, cargo honroso, recibir grados académicos, pasar a las Indias, adomarse con oro y vestir seda ${ }^{13}$. Aunque el rey jamás aplicó esta pragmática a sus favoritos.

Siete años más tarde, el Rey Católico secularizó la pragmática y, mediante buenas sumas de dinero, compuso por etapas el estado de los inhábiles. Así que en 1508 cobró, solamente de los 500 hombres registrados en el Padrón de Conversos de la comarca de Sevilla ${ }^{14}$, veinte mil ducados, devolviendo a los penitenciados sus bienes confiscados por el Santo Oficio. En el año siguiente recaudó en el mismo lugar ochenta mil ducados, habilitando a los mismos para toda clase de oficios públicos, excepto los de corregidores y alcaldes con jurisdicción criminal. Pronto, la composición legalizaba la estancia de los cristianos nuevos que ya vivían en América, y permitia a todos los otros participar en el descubrimiento, colonización, administración y comercio con las tierras de ultramar. De aquí que entre los años 1509 a 1518, los cristianos nuevos participaron activamente en la emergente vida americana. Sus nombres y ocupaciones aparecen en diversos catálogos de pasajeros, índices geobiográficos y otras listas.

Entre todos ellos se encontraba Juan de Córdoba ${ }^{15}$, platero y notable mercader de perlas que importaba de la isla de Cubagua, situada frente a Venezuela entre 1517 y 1522 . Años más tarde llegó a ser uno de los 24 concejales de Sevilla. En 1519 le prestó a Hernán Cortés una gran cantidad de dinero que el Capitán empleó en la consumación de la conquista de México-Tenochtitlán. El préstamo fue negociado por el licenciado Francisco Núñez de Valera, prominente cristiano nuevo de Salamanca, casado con Inés Gómez de Paz, tía paterna del Conquistador, en cuya casa Cortés se hospedaba durante sus años de estudiante. Núñez era su procurador en la Corte y, en 1522, un año después de la conquista de México, envió a sus hijos, encabezados por el mayor, Rodrigo de Paz, con dos cédulas Reales a México-Tenochtitlán. La una nombraba a Cortés Capitán General y Gobernador de la Nueva España, y la otra ordenaba la expulsión de todos los descendientes de moros y cristianos nuevos del Cuarto Continente. Ambas fueron expedidas en nombre de Carlos I de España y V del Sacro Imperio Germano-Romano. Sin embargo, ni Cortés ni nadie de los otros capitanes publicaron esas órdenes para evitar revueltas en sus huestes.

13 Antonio Dominguez, Los judeoconversos en España y América, pp. 50 - 51 .

14 Claudio Guillén, "Un padrón de conversos", en Bulletín Hispanic, 1963, T. 65, pp. 79 - 80.

15 Enrique Otte, Las perlas del Caribe: Nueva Cádiz de Cubagua, Fundación John Bulton, Caracas, 1977, pp. 67, 72 y siguientes listas, p. 403; Ruth Pike, Aristocratas y comerciantes. La sociedad sevillana en el siglo $X V l$, Ariel, Barcelona, 1978, p. 105. 
La publicaron los oficiales reales provocando el acusarse los unos a los otros, y trataron de expulsar a algunos. Pero finalmente se quedaron casi todos, gracias al apoyo de sus colegas de armas. En cambio en Cubagua, el mismo día del pregón, el 14 de diciembre de 1522, Pedro de Barrionuevo, sobrino de uno de los hombres más ricos de la isla, se dirigió al anochecer a la tienda de Martín Alonso Alemán, natural del condado de Niebla, y después de gritarle "perro judío" lo acuchilló hasta que expiró. Martín llegó muy joven a las islas y se dedicaba a la pesca de perlas y de otros productos marinos. Fue distinguido por Carlos $\mathrm{V}$ con el nombramiento de regidor vitalicio de la ciudad, después de lanzarse con su bergantín contra un grupo de piratas que atacaba la isla. Sin embargo, Barrionuevo consideró que matar a un judio, aunque ya estaba asimilado a la vida de los cristianos viejos, no era pecado ${ }^{16}$.

$Y$, aunque se pretendía expulsar a otros cristianos nuevos, cuyos nombres aparecen en el mencionado pregón, nadie abandonó el Cuarto Continente, sino tan solo se cambió de lugar, emigrando a la Nueva España.

Del mismo condado de Niebla, de Palos, era natural también Hernando Alonso, de profesión herrero. En 1517 vivía en Cuba, dedicándose a la cría de carneros y puercos. En 1519 abasteció con carne a la hueste de Hernando Cortés, que estaba por lanzarse a la conquista del Imperio Mexica. Meses más tarde arribó a Veracruz para unirse a Cortés y, como herrero que era, trabajó bajo las órdenes del famoso carpintero Martín López, constructor de los bergantines que jugaron un papel primordial en la conquista de México-Tenochtitlán. De inmediato le fue concedida una encomienda (porción de tierra con posibilidad de riego e indígenas para labrarla), y un solar "para que labre y edifique su casa". Alonso, como algunos otros conquistadores, consideró el tributo y trabajo indigena solamente como un medio para conseguir capital y lanzarse a nuevas empresas. Desde un principio compitió por el contrato de proveedor de carne para la ciudad de México, lo que logró abaratándola de 6 a 4 reales el arrelde en 1524. Luego formó una compañía de tipo capitalista, tras otra con diferentes conquistadores para la crianza de ganado menor y para explotar minas de oro y plata. También utilizaba socios activos a los cuales pagaba con un porcentaje de las ganancias. Hacia la mitad del año de 1528 , tenia tres compañias mineras y varios criaderos de ganado, además de sus encomiendas en las que cultivaba trigo y legumbres, además de maiz para sus trabajadores indígenas. Sin embargo, no pudo gozar de sus encomiendas y minas y tampoco cumplir con sus otras obligaciones, pues el 16 de octubre de 1528 fue quemado por judio y sus bienes fueron confiscados por los frailes de la Orden de Santo Domingo ${ }^{17}$.

Las actividades de Hernando Alonso no diferían de las de otros conquistadores-encomenderos que, como hijos de su tiempo, amaban la aventura y el oro conquistado y, al mismo tiempo, cimentaron las bases del Imperio español. Sin embargo, esta virtud no podia salvar a un hombre de las llamas. Hernando Alonso, cuyo sambenito estaba colgado en la Catedral de la Ciudad de

if Enrique Otte, Las perlas del Caribe..., pp. 410, 436, 500.

17 Eva A. Uchmany, "De algunos cristianos nuevos en la conquista y colonización de la Nueva España" en Estudios de Historia Novohispana, Instituto de Investigaciones Históricas (en adelante, IIH), UNAM, México, 1985, vol. 8, pp. 265-318. 
México aún a principios del siglo XVIII, casó por tercera vez con "Isabel Ruiz de Aguilar, fermosa hija de un Aguilar, sastre tuerto de un ojo"1". La bella dama fue la causa de su perdición, pues fue acusado de prohibirle ir a misa durante su regla por observancia de la Ley de Moisés ${ }^{19}$. Según un testigo ocular, Alonso le dijo a su mujer que se estaba recuperando de un parto, en presencia de otros hombres: "...estáis de arte que inviolareis la Iglesia"; y, como este testigo se lo oyó, le dixo: "esas son ceremonias antiguas de los judios, y ya no se guardan después que tenemos la ley de gracia evangélica"; a lo cual el dicho Alonso no le respondió ninguna cosa, ni este testigo reparó en ello, pareciéndole que serían achaques del dicho Hernando Alonso, para que su mujer no saliese fuera"20"

Pocos meses después que ocurrió esa plática, el herrero fue denunciado por un rico comerciante de Sevilla, Antón Ruiz de Maldonado, que se encontraba en aquella trágica mañana dominical en su casa, y quien en la primera ocasión que tuvo corrió a denunciarlo con fray Vicente de Santa María.

El celoso dominico hizo de inmediato una investigación, en la que resultó que años atrás, aủn en Cuba, Alonso participó en una ceremonia de Pascua en la que cantaban Dominus Deus de Israel de Egipto, o sea, el Salmo $114^{21}$. Además, fue acusado de haber bautizado dos veces a un niño que tuvo con una indígena o mestiza.

Pedro Vázquez de Vergara, gran amigo de Alonso y compañero en la construcción de los bergantines, que presenció el auto de Fe en 1528 , oyó decir unos años más tarde a don Sebastián Ramírez de Fuenleal, quien llegó a México en 1530 como presidente de la Audiencia Real, “...que no se había guardado, con los dichos Hernando Alonso y Gonzalo de Morales el modo de proceder en el orden jurídico que se había de guardar, lo que sabía como inquisidor que lo había sido en España, y que se les había hecho agravio en no admitirlos a misericordia, pues la habian pedido dende a poco de cómo habían negado [sic]"22.

18 "Testimonio de Bartolomé González", en "Diligencias sobre los Sanbenitos antiguos y renovación de cllos, y postura de los que se han relaxado y requerido por este Sanio Oficio", México, 1574, Archivo General de la Nación de México (en adelante, AGNM), Inquisición, v. 77, exp. 35, $63 \mathrm{f}$. Las Diligencias son un documento redactado por el Licenciado Bonilla, secretario del Tribunal del Santo Oficio en la Nueva España, en 1574. Bonilla inició una pesquisa sobre los procesados por el Primitivo Tribunal, con el fin de colgar nuevamente los sambenitos de los primeros penitenciados en la Catedral, como una forma de seguir difamando su memoria.

1) En el judaísmo, las mujeres durante su menstruación son consideradas impuras; antiguamente, en este estado, no entraban al templo y hasta la actualidad no tocan las Sagradas Escrituras. Así mismo, las mujeres que acababan de dar a luz deben esperar un lapso de cuarenta dias para incorporarse a la vida normal. "Testimonio de Pedro Vázquez de Vergara, natural de Sevilla, de edad de más de setenta años", en "Diligencias sobre los Sambenitos antiguos y renovación de ellos...", México, 1574, AGNM, Inquisión, v. 77, exp. 35.

28 "Cuando Israel salió de Egipto, la casa de Jacob del pueblo extranjero", Salmo CXIV.

22 "Testimonio de Pedro Vázquez de Vergara..." en "Diligencias sobre los Sambenitos antiguos y renovación de ellos...", v. 77, exp. 35 . 
Gonzalo de Morales arribó a la Nueva España en 1520 y cinco años más tarde se le otorgó un solar en la ciudad de México. Fue un pobre mercader que en 1528 fue acusado de vivir amancebado. Sin embargo, de repente llegó un informe enviado por Alonso Manso, obispo de San Juan de Puerto Rico, quien había quemado a su hermana, que confesó, que en la compañía de su hermano Gonzalo y un tal Palma, "habían azotado un crucifijo" ${ }^{\text {"23 }}$. En vista de ello y sin más indagaciones, Vicente de Santa María lo quemó. En este mismo auto fue también penitenciado otro hermano de los Morales, Diego, quien hizo el ofício de calcetero en Cuba y, por su honestidad, muchos mercaderes y conquistadores le confiaron cartas de poder, para cobrar a sus deudores. En esta ocasión fue penitenciado por blasfemo, delito que había abjurado un año antes, en el auto organizado por fray Domingo de Betanzos, meses después de su llegada a México ${ }^{24}$.

Los dominicos prestaron de inmediato su apoyo a los oficiales reales en su pugna contra los conquistadores-encomenderos por el control de la Nueva España. Los últimos gozaban de la simpatía de los franciscanos, que arribaron a México en 1524. De aquí que en este primer auto desfilaron diecisiete conquistadores por blasfemos, entre ellos algunos reconocidos como cristianos nuevos. Betanzos estaba decidido a expulsarlos y devolverlos a España, aunque no lo logró y, por tanto, los conquistadores Diego Núñez, Bartolomé Quemado y otros se quedaron, aunque fueron obligados a pagar una multa exorbitante de 400 maravedíes $^{25}$, mientras que los otros blasfemos pagaban tan solo $5 \circ 7$ pesos de oro de tepuzque ${ }^{26}$. La blasfemia consistía, por lo general, en decir en momentos de ira "pese" o "reniego de..." Virgen, santos, crisma, y otras palabras escandalosas.

Vicente de Santa María era más original que Domingo de Betanzos, pues al acusar a Diego de Morales por las mismas blasfemias por las que ya había sido castigado en 1527, le cobró de nuevo una elevada multa pecuniaria y, además, le amordazó la lengua colgando el lazo del instrumento sobre un árbol. Para que la lengua no se le arrancase se vio obligado a pararse sobre las puntas de sus pies y así permaneció a lo largo de cuatro largas horas que duró la ceremonia del auto. En este estado presenció la quema de su hermano mayor. La terrible muerte de sus seres queridos, sus propios sufrimientos y humillación lo transformaron en un ser inadaptable al medio en el que le tocó vivir, pues antes de la mitad del siglo desfiló aun en otros cuatro autos y era difamado en toda la Nueva España, Guatemala y otras partes ${ }^{27}$.

${ }^{3}$ "Testimonio de fray Vicente de las Casas", en "Diligencias sobre los Sambenitos antiguos y renovación de ellos...", v. 77 , exp. 35 .

24 "Proceso contra Diego de Morales por blasfemo y hereje", México, 1528, AGNM, Inquisición, v. I, exp. 11, f. 28-44; "Proceso contra Diego de Morales por blasfemo", México, 1524-1525, AGNM, Inquisición, v. 1, f. 93-134.

zs "Proceso contra Diego Núñez por blasfemo", México, 1527, AGNM, Inquisición, t. 1, exp. 7; "Proceso contra Bartolomé Quemado por blasfemo", México, 1527, AGNM, Inquisición, t. 1, exp. 9.

26. Un peso de oro de tepuzque equivalía a 34 maravedís cada uno, y era el más bajo; por lo general cada peso equivalia a 8 reales de plata. Peter Boyd-Bowman Léxico hispanoamericano del siglo XVI, Londres, Tamesis Books Limited, 1971.

27 Véase al respecto de Ios hermanos Morales, en Eva A. Uchmany, "De algunos Cristianos Nuevos....", en Estudios de Historia Novohispana, pp. 296-305. 
En el mismo auto de fe desfilaron también dos famosos escribanos, naturales de Sevilla y de origen hebreo. Juan Fernández del Castillo se embarcó para las Indias en 1516 en calidad de "escribano de sus Altezas". Ejerció su oficio tanto en las Islas como en la ciudad de México, donde fue reconocido por muchos, incluyendo el licenciado Marcos Aguilar, gobernador de la Nueva España entre 1526-1527, quien se acordaba de su padre, de oficio espejero, y quemado en Sevilla por judaizante. Del Castillo fue acusado en el verano de 1528 por hacer idolatrar a los indígenas colocando unas estatuillas de perros adornados con papel recortado en sus ventanas, según lo usaban los naturales con sus víctimas destinadas al sacrificio. Requerido por sus actos, confesó rápidamente y pidió perdón ${ }^{28}$. Fue reconciliado en un auto particular en agosto de 1528 . El día del Auto público, el 17 de octubre, "agradeció a Dios por haberle salvado la vida", según lo anotó en su libro de Notarías ${ }^{29}$. Ocho años más tarde, en 1536, fue encarcelado de nuevo, esta vez por ateo. Pero no lo era sino más bien se volvió escéptico en materia de fe, lo que sucedió a muchos después de haber sido encarcelados por el Santo Oficio.

Cabe subrayar que el primer proceso de Juan Fernández del Castillo, que sobrevivió hasta nuestros días, guardado en el AGN, fue despojado de varias fojas recortadas con tijeras, en fecha anterior a 1975, cuando lo leí por vez primera. Es de suponerse que algún familiar escandalizado trataba de eliminar la evidencia del origen hebreo de uno de sus ancestros, purificando así su sangre contaminada en el siglo XX.

Diego de Ocaña llegó a las Indias en 1509 con la flota de Diego Colón, probando su suerte en Santo Domingo como mercader. En 1525, a la edad de sesenta años, llegó a la ciudad de México. Desde un principio "en toda esta ciudad...era habido y tenido comúnmente por confeso de generación de judios... de la casta de unos Xuárez de Benadeva, judíos de Sevilla" ${ }^{30}$. Era allegado del factor Gonzalo de Salazar, a quien servía de secretario y también era amigo del gobernador Alonso de Estrada, hijo natural de Fernando el Católico y una de las bellezas judías de Ciudad $\mathrm{Real}^{31}$. Ambos estuvieron presentes en el Auto de $\mathrm{Fe}$ en el que fue penitenciado y salvaron la vida a este visionario que defendía el gobierno del Emperador en contra de los conquistadores. Cabe mencionar que Ocaña envió dos cartas al Consejo de Indias, escribiéndole al emperador de que si Cortés se quedaba con el reino de la Nueva España "morirá con Corona"32. La opinión del escribano junto con otros informes fueron tomadas en cuenta por el Consejo de Indias, y muy

A. Millares Carlo y J. I. Mantecón, Indice y extracto de los Protocolos del Archivo de Notarias, Colegio de México, México, 1945, t. I, p. 353.

"Proceso contra Juan Femández del Castillo por blasfemo", México, 1536, AGNM, Inquisición, vol. 14, exp. 14 , ff. 118-119.

"Testimonio de Pedro Vázquez de Vergara"; "Testimonio de Diego de Valadéz", conquistador de esta tierra de más de ochenta años; "Testimonio de Bartolomé González" natural de Mari-Alva, Portugal, en Diligencias sobre los Sambenitos antiguos y renovación de ellos..., v. 77, exp. 35.

31 Francisco Fernández del Castillo, "Alonso de Estrada y su familia" en Memorias de la Academia Mexicana de la Historia, México, 1942, T. I, pp. 398-431; Norberto Castro y Tosi, "Verdadera paternidad de Alonso de Estrada", en Revista de Indias, Madrid, 1948, vol. 9, pp. 1011-1026.

2 "Carta de Diego de Ocaña al Consejo de Indias, México 9 de septiembre de 1526", en Joaquín García Icazbalceta, Colección de documentos para la historia de México, Porrúa, México, 1971, T. I, pp. 524-557. 
pocos años después, el Conquistador perdió el gobierno de la Nueva España para siempre. Así mismo, Ocaña aconsejaba al Emperador que cimentase su imperio universal sobre un poderio económico, basado en la producción y venta de especias, sembrándolas en la Nueva España, cuya tierra era apta para ello. Consideró que de esta forma abarataría la producción y el precio de las mismas, y asi "daría un golpe mortal al trato de Portugal con el Levante". Sin embargo, nada le valieron a este castellano sus preocupaciones por el bienestar de su patria frente a un fraile celoso y cruel a quien los monarcas de España otorgaron el poder absoluto sobre la vida y la muerte de sus súbditos y, aun más, de los de segunda clase en cuyas venas corría sangre hebrea.

Sin duda habia excepciones, como lo era el gobernador Alonso de Estrada, natural de Ciudad Real, casado con Marina de la Caballería, hija de una famosa familia de cristianos nuevos que aceptó el bautismo a finales del siglo XIV. El gobernador llegó acompañado por su primo Diego de Mazariegos y un grupo de jóvenes de su ciudad natal, a quienes envió a pacificar y colonizar la provincia de Chiapas ${ }^{33}$. Sus apellidos, e incluso nombres, coinciden con las listas de judaizantes penitenciados por la Inquisición en Ciudad Real, estudiada y publicada en cuatro volúmenes en Israel por el profesor Haim Beinart ${ }^{34}$.

En vista de que no todos los cristianos nuevos gozaban de la condición del gobemador Estrada, se valían de otros medios para hacer olvidar su origen. Rodrigo de Orgóñez, natural de Oropeza, hijo de un pobre zapatero remendón, quien se bautizó semanas antes de la expulsión de los judíos de España y de inmediato se dirigió a Italia. Allí se enroló en el ejército de Carlos $\mathrm{V}$, quien trataba de obligar al Papa para que lo coronase. Participó en diversas batallas, incluyendo la de Pavia (1525), en la que estuvo entre los captores del monarca francés Francisco I. Luego regresó a Oropeza por su hermano Diego Méndez y juntos se embarcaron hacia las Indias. Ambos tomaron parte en diversas expediciones en el Istmo, Honduras y en el Perú. La valentía de Orgóñez lo hizo uno de los capitanes más allegados de Diego de Almagro, cuyo origen es también dudoso. Destacó con su hermano Diego en la conquista de Cuzco, de Chile y en otras muchas batallas y expediciones. Al no poder revelar su origen hebreo y recibir los honores merecidos por sus actos, le enviaba un sin fin de regalos de oro y plata a un noble español llamado Juan de Orgoñoz, tratando a persuadirlo que es su hijo natural. Entre otras cosas, le envió desde Cuzco, el 3 de julio de 1535, la siguiente carta: "Señor, lo que más os pido es que finalmente me reconozcáis como su hijo legítimo, pues solamente así podría conseguir mi merecido "hábito de Santiago"'s. Sin embargo, Juan de Orgoñoz no se dejó convencer.

Pero, en ocasiones, ni el hábito de Santiago logró legitimizar a descendientes de cristianos nuevos, como lo era también el caso de Alonso de Ávila, sobrino y homónimo del secretario

33 Comunicación verbal de la Dra. Gudrun Lohmayer, mayóloga. Algunos casos son mencionados en su libro Génesis histórica de Chiapas 1522-1532. El conficto entre Portocarrero y Mazariegos, Instituto de Investigaciones Filológicas, UNAM, México, 1993.

34 Haim Beinart, Records of the Trials of the Spanish Inquisition in Ciudad Real, The Isracl Academy of Sciences and Humanities, Jerusalem, 1974, 1977, 1982, 1986. 4 vols.

35 John Hemming, The Concuest of the Incas, Macmillan \& Co, Londres, 1970. 
converso de Isabel la Católica ${ }^{36}$. Su sobrino Gil González Benavides de Ávila, contador real, llegó en 1509 a Santo Domingo, en 1511 dejó su puesto a su sobrino Alonso de Ávila, y en 1514, don Fernando le concedió el hábito de Santiago y licencia para buscar un estrecho entre los dos océanos. Estando en eso, en 1519 sojuzgó a Costa Rica y Nicaragua. Sus sobrinos Alonso de Ávila y Gil González de Benavides de Ávila se embarcaron en 1517 a México con la armada de Juan de Grijalva. El primero como contador real y el segundo como capitán de uno de los barcos. En 1519, ambos se alistaron en la expedición de Cortés con los mismos cargos. En 1520, Alonso fue nombrado alcalde de la recién fundada Villa Rica de la Vera Cruz, y dos años más tarde, Cortés lo envió con el tesoro de Motecubzoma a España como su procurador privado. En el camino fue preso junto con el tesoro por el corsario francés Juan Florín. En 1524 fue liberado y en 1527 regresó a Nueva España como uno de los capitanes de Francisco de Montejo, que traía consigo un considerable número de cristianos nuevos, quienes se embarcaron sin los debidos certificados de limpieza de sangre, pues Montejo dio garantías de que ninguno de ellos tenía sangre contaminada ${ }^{37}$. Diez años más tarde, en 1537, el obispo e inquisidor apostólico de la Nueva España, Fray Juan de Zumárraga, lo acusó de pisar un crucifijo que supuestamente tenía bajo su escritorio ${ }^{38}$. Era ésta una clásica acusación contra muchos judíos y cristianos nuevos y sirvió al Inquisidor como un pretexto para difamar al contador real y conquistador de México y de Yucatán. El Inquisidor odiaba a Alonso de Ávila porque se atrevió a advertir a su amigo, al cristiano nuevo Gonzalo Gómez, uno de los fundadores de la ciudad de Guayanguareo (actualmente la ciudad de Morelia, capital del Estado de Michoacán) de que el Inquisidor Apostólico lo iba arrestar. En definitiva, ningún cristiano viejo hubiera hecho este favor a un cristiano nuevo $0^{39}$.

Su hermano Gil González de Benavides de Ávila, conquistador de la Nueva España, alcalde electo de México-Tenochtitlán, se casó en 1527 con doña Leonor de Alvarado, sobrina del conquistador Juan de Alvarado. Sus dos hijos, Gil y Alonso, eran grandes amigos de don Martín Cortés, hijo del Conquistador y II Marqués del Valle de Oaxaca, acusado en 1566, de organizar una supuesta conspiración contra la Corona. Don Martín fue exiliado a España y los González de Ávila fueron encarcelados y, el mismo día, al anochecer, decapitados sin proceso alguno y sus cabezas se exhibieron en la picota ${ }^{40}$.

3* "Averiguación hecha por el Santo Oficio en lo de Alonso de Avila, acusado de tener un crucifijo debajo de su escritorio y poner los pies encima", AGNM, Inquisición, México 1537, vol. 1, exp. 23 bis.

39 Véase también en Eva A. Uchmany, "The Participation of New Christians and Crypto-Jews in the Conquest, Colonization and Trade of Spanish America, 1521-1660", en The Jews and the Expansion of Europe to the West. 1450-1800, edited by Paolo Bernardini \& Norman Ficring, The John Carter Brown Library \& Berghahn Books, New York-Oxford, 2001, pp. 186-202.

40. Guillermo Porras Muñoz, El gobierno de la Ciudad de México en el siglo XVl, México, $111 \mathrm{H}$ UNAM, , 1982 , pp. 303-306. 
Fueron los únicos de todos los amigos del Segundo Marqués en sufrir este rápido e inhumano castigo, sin duda debido a su remoto origen hebreo, que la acusación del obispo Zumárraga, quien juzgó no tan solo con suma severidad sino con gran pasión a todos los reos, puso en evidencia.

Gonzalo Gómez, hijo de madre quemada y padre penitenciado, arribó a la Española en 1507 a los doce años de edad, en compañia de su padre. En 1514 se unió a la hueste de Pedro Arias Dávila, también de origen hebreo, y participó en la conquista del Darién; luego tomó parte en la conquista de la Nueva España. Pertenecía al grupo de Cortés, quién le otorgó una encomienda en Yxtapa, Michoacán, y otros bienes. Fue de los primeros fundadores de Guayanguareo, actual Morelia. Se dedicaba a la ganadería y a la minería. También introdujo telares españoles a México, y enseñó a los indios de Tezcoco el modo de producir telas finas. Luego abrió la primera tienda de ropa en la ciudad de México. Pronto se enriqueció y provocó envidias, en particular de los oficiales reales y otros, que buscaban los caminos para quitarle la encomienda, y quienes lo insultaron llamándole "perro judio", a pesar de que era totalmente asimilado al modo de vida de los cristianos viejos. En junio de 1537, Zumárraga firmó la orden de aprehensión en su contra con confiscación total de sus bienes; sobre su cabeza pendian trece graves cargos y el Inquisidor estaba decidido a expulsarlo de la Nueva España. En 1543 la Corona revocó los poderes inquisitoriales del obispo Zumárraga por haber quemado al Cacique de Texcoco. Por tanto, Gómez tuvo la posibilidad de defenderse, aunque fue obligado a pagar una notable multa de 400 pesos de oro de minas. Además, los que instigaban en su contra seguían inventando nuevas acusaciones hasta que en la primavera de 1554, el corregidor Lope de Saavedra recibió una Cédula Real, en la que se le decía que: "vos por odio... e por molestar, por vuestra propia autoridad andays fiziendo pesquiza..." firmada Yo, la Reina ${ }^{41}$. Finalmente, Gonzalo Gómez pudo casar a todos sus hijos e hijas con las familias más importantes y célebres de la Nueva España ${ }^{42}$.

Los aires de la Contrarreforma se hicieron sentir también en los dominios allende el mar y demostraron al Doctor en Cánones, Christóbal de Miranda, que los cristianos de segundo grado, aunque fuesen educados desde la más tierna edad en las ciencias de la Iglesia Universal, eran inaptos para servirla. Miranda desembarcó en Veracruz en compañía de su padre, Juan de Miranda en 1551, para ocupar el cargo de Primer Deán de la Iglesia catedral de Mérida en Yucatán. Junto con el nombramiento para la dignidad que iba a ocupar llevaba sus cartas de limpieza de sangre. Dos años mảs tarde, el deán fue nombrado también Comisario del Santo Oficio en Yucatán. Tuvo mala suerte y fue reconocido por uno de los feligreses y, de inmediato, se abrió una nueva investigación acerca de sus antepasados. De ésta resultó que sus bisabuelos maternos, Diego Donaire, tejedor de mantas, e Isabel García, fueron quemados como los peores judíos dogmatistas en el puerto de Santa María, en los alrededores de Sevilla en 1516. Sus abuelos paternos, Diego

41 "Proceso contra Gonzalo Gómez por palabras malsonantes...", México, 1536, AGNM, Inquisición, vol. 2 , exp. 2, $77 \mathrm{ff}$. numeradas y $54 \mathrm{ff}$. sin numerar.

42 Eva A. Uchmany, "De algunos cristianos nuevos...", en Estudios de Historia Novohispana, vol. 8, p. 279. 
López, mercader, y Leonor Rodríguez, fueron penitenciados en la misma localidad ${ }^{43}$, según lo indicaban sus sambenitos colgados en la lglesia principal del puerto ${ }^{44}$. De aquí se puede deducir que el padre del Déan compró a los testigos de la primera probanza, práctica común en España, que podría asegurar a las personas una vida tranquila e incluso exitosa ${ }^{45}$.

Por su parte, Hernando Ortiz de Hinojosa, quien nació en 1544 en San Lúcar de Barrameda y llegó como niño a la Nueva España, se doctoró en cánones y teologia en la Universidad de México y luego fue honrado con la prima de cátedra de teología y, a la vez, fue también nombrado en 1592 abogado del Santo Oficio. De inmediato se hizo una extensa pesquisa sobre sus origenes y se demostró que sus abuelos paternos Hernando Ortiz de San Lúcar era apodado "el rey de los judíos", y Violante Hernández, eran confesos y notorios descendientes de judíos, llanos y habidos por tales"46.

La noticia llegó a México el 1 de diciembre de 1592. De inmediato, después de terminada la lectura de los despachos, Hinojosa fue despedido del Santo Oficio y, por la exigencia de los inquisidores, también de la Universidad. Sus sobrinos, casados con las más honradas familias de la ciudad, fueron desde aquel trágico día difamados ${ }^{47}$. De aquí que la España de los Reyes Católicos, que buscaban unir a los habitantes de su reino por medio de una fe que nació en el judaísmo y cuyos fundadores eran judíos así como sus principales santos, llegó a desembocar en menos de un siglo en la antesala de un feroz racismo que pensaba con la sangre y las entrañas y no con la razón.

En efecto, los cristianos nuevos de origen español que emigraron hacia las Indias Occidentales, así como la mayoría de los que no abandonaron su tierra natal a la hora de la expulsión, estaban ya adaptados en su inmensa mayoría al modo de vida del resto de los españoles. En cambio la mayoría de los portugueses, quienes no tenían la libertad de escoger su fe, seguían siendo en su mayoría judíos convencidos y tan solo una minoría de ellos, dependiendo de las condiciones en los que se educaron, abrazaron el cristianismo sinceramente.

En definitiva, la mayoría de los hebreos de origen portugués siguieron fieles a su religión ancestral y con todos los esfuerzos y riesgos que esto implicaba, seguian educando a sus hijos en el judaísmo.

"Cartas dirigidas al Santo Oficio desde Mérida Yucatán, 1575, AGNM, Inquisición, vol. 79, exp. 10; vol. 80, exps, 8, 10,11,21. Año 1579 .

44 Eva Uchmany, "De algunos cristianos nuevos en la conquista y colonización de la Nueva España" en Estudios de Historia Novohispana, México UNAM, vol. 81985.

45 "Cartas dirigidas al Santo Oficio desde Mérida, Yucatán", 1575, AGNM, Inquisición, vol. 79, exp. 10; vol. 80 , exps. 8, 10, 11 y 21 , año 1579 ; y vol. 82, exp. 14.

46 Javier S. Sánchiz Ruiz, La limpieza de sangre en la Nueva España el funcionariado del Santo Oficio de la Inquisición, siglo XVI. Tesis de Maestría, UNAM, 1990, pp. 109-112.

47 Eva A. Uchmany, "Identidad y asimilación: cristianos nuevos y criptojudios en la Nueva España “, en Judith Bokser Liwerant y Alicia Gojman de Backal, Encuentro y Alteridad: vida y culnura judia en América Latina, México, FCE, 1999, pp. 73-84. 


\section{LA CORONA UNIDA}

Los portugueses se convirtieron en súbditos de la Corona de España en 1580, cuando Felipe II fue nombrado Rey de Portugal. No recuperarían su autonomía hasta 1640. Durante el periodo que va de 1580 a 1640, los portugueses abundaron en España y también en sus dominios allende el mar. Cabe señalar que un notable número de ellos no eran solo cristianos nuevos, sino también criptojudios. Varios de ellos se habían establecido temporalmente en juderías en Italia y otros lugares, desde donde se dirigían a España, tanto en búsqueda de libertad religiosa como de fortuna. Gran cantidad de ellos se esparcía en los vastos territorios de sus colonias en los que se descubrieron en años anteriores ricos yacimientos de plata y oro. Además, el descubrimiento de la ruta hacia las Filipinas ofrecía a los hombres emprendedores nuevos horizontes. Por otro lado, el monarca portugués no se podía permitir la pérdida de sus súbditos más activos, que además eran los tributarios más importantes al fisco debido a las exenciones de las que gozaba la nobleza y el clero. Por cierto, durante el reinado de don Manuel entraban en las cajas reales, anualmente, tan solo de la Costa de Oro de África, alrededor de 170000 cruzados de oro.

Un gran número de cristianos nuevos, de origen lusitano, vivía hacia adentro, en la intimidad de sus hogares, como judios, aunque debido a las circunstancias, lo hacían en ropaje de cristianos. Fue ésta la consecuencia de la coerción religiosa practicada por Don Manuel l que condujo, en la Semana Santa de 1497, a todos los judíos portugueses junto con sus intelectuales y rabinos, contra su expresa voluntad ${ }^{48}$, hacia las pilas bautismales. Es obvio que la fuerza bruta no logró convencerlos de la autenticidad del cristianismo. Aun más, por negarles el libre albedrío, los hizo apegarse con toda su razón y corazón a su credo ancestral, en el que educaban a lo largo de los siglos a sus hijos y nietos.

Después de retenerlos en Portugal, el monarca les concedió un lapso de veinte años, durante los cuales nadie debería indagar acerca de la ortodoxia de sus prácticas religiosas. Sin embargo, dos años más tarde el voluble don Manuel cambió de parecer y el 20 y 21 de abril de 1499 expidió dos albarás o Cédulas por medio de las que prohibía a los conversos vender sus bienes raíces y les vedaba abandonar el reino. Discriminados de esta manera, fueron el blanco de burlas y agresiones de la emergente burguesía con la que competían. De aquí que el pueblo instigado por frailes fanáticos los odiaba aun más que antes. Además de las envidias económicas y celos religiosos se sumó la peste, el gran azote de los siglos XIV y XV. Como siempre, los judios fueron acusados ser su causa y efecto.

En 1506, la peste hacía estragos en Lisboa, razón por la que Don Manuel y los nobles se mantenían alejados de la ciudad. Durante la Semana Santa, en la catedral, que en aquél entonces

4 Véase en Amador de los Rios, Historia Social ..., p. 743, nota 1. citando a don Fernando Coutinho, obispo de Silves, acerca de la forzada conversión, "Patrem filium adducentem, cooperto capite in signum maximae tristitiae et doloris, ad pilam baptismatis, protestando et deum in testem recipiendo, quod volevant mori in lege Moyse". Y podríamos citar a muchos teólogos contemporáneos al respecto. No obstante nadie hizo nada, nadie excomulgó al rey y tampoco le reprochó su acto. 
estaba repleta de gente, incluyendo a los neófitos, alguien puso en una ventana detrás de una cruz dos velas, que la iluminaban de una manera extraña. De pronto se oyó una voz gritando ¡Milagro! Al instante, los presentes fueron poseidos por una locura sagrada, aprovechada de inmediato por dos frailes dominicos, que levantando un crucifijo señalaron a los conversos y gritaban: "iherejía!" Fue ésta la señal. La masacre duró tres días sucesivos. Más de tres mil personas fueron asesinadas en la ciudad y cientos en los alrededores. La mayoría de las casas de la Rua Nova, la antigua juderia, fueron saqueadas y destruidas. El rey envió de inmediato un ejército hacia la ensangrentada Lisboa a la que despojó por tres años del título "noble y leal". Los dos dominicos fueron públicamente agarrotados y quemados. Don Manuel, conmovido por la tragedia, anuló la pragmática de 1499 , que prohibía a los conversos disponer de sus personas y bienes, y solemnemente ratificó la Cédula de 1497. Además, prohibió inquietar a los neófitos durante los próximos diez años que faltaban para el cumplimiento del plazo de la ley de tolerancia. En 1512 , el monarca extendió el tiempo de la tolerancia religiosa, que debería expirar el 30 de mayo de 1517 , hasta el 30 de mayo de 1534. A simple vista parecía que a los conversos se ofrecia una era de bonanza y estabilidad en Portugal; sin embargo no era así.

La emergente burguesía vigilaba celosamente la ortodoxia de los neófitos, sus potenciales competidores a quienes las aguas bautismales abrieron enormes posibilidades económicas, incluyendo el comercio marítimo. El populacho -compuesto en gran medida por vagos y personas recién venidas del campo, que buscaban ocupar los lugares de los desaparecidos en las periódicas pestes- deseaba convertirse rápidamente en burguesía acomodada $\mathrm{y}$, por tanto, estaba siempre listo para hacer buenas obras asaltando y saqueando viviendas de herejes. Todos ellos fueron frecuentemente atizados por frailes fanáticos que sembraban rumores acerca de cristos, virgenes y hostias desacralizados. En 1515 fueron pegados en los sitios públicos de Lisboa pasquines que exhortaban pasar a cuchillo a todos los conversos. Los manipuladores de los ímpetus populares influyeron también en la Corona, pues Don Manuel, tres años después de la promulgación del edicto de extensión de la tolerancia religiosa, procuraba una Bula papal para establecer en sus dominios el Tribunal de la Inquisición. Pero el tolerante Giovanni de Médici se la negó por no respetar el libre albedrío de los judíos. En respuesta, el ofendido monarca anuló el 4 de abril de 1521 el arriba mencionado decreto y prohibió a los cristianos nuevos disponer de sus bienes y abandonar Portugal.

De aquí que los cristianos nuevos que lograron evadirse de su tierra natal entre los años 1507 a 1521 se consideraban afortunados. Todos ellos se dispersaron en las diversas juderías europeas, incluyendo las italianas, con preferencia en los estados papales y en el ducado de Ferrara, en donde fueron bien recibidos. Sin embargo, unos treinta años más tarde, sus libertades y derechos fueron restringidos por los papas de la Contrarreforma. Se les obligó vivir en ghettos, lo que significaba la reducción de sus viviendas casi a una sola habitación, pues las juderias disponían, por lo general, solamente de una calle. Además, les estaba prohibido vender artículos de primera necesidad y cosas nuevas. Estas y otras disposiciones transformaron a la inmensa mayoría de los hebreos en miserables zurcidores y ropavejeros. Incluso estaban obligados a escuchar en sus propias sinagogas, cada sábado, un sermón de algún fraile que trataba a convertirlos al cristianismo. 
Los que podian buscaban nuevos horizontes. Unos se dirigían a Holanda e Inglaterra, otros a Turquia, al Medio Oriente, e incluso al Sudeste de Asia, en donde existían florecientes comunidades hebreas muchos siglos antes de la llegada de los portugueses. En una de las surgidas en el siglo XIII o antes, en Cochin, India, destacaban algunas familias con apellidos hispanos como Castellán y semejantes ${ }^{49}$. Una notable cantidad de ellos hablaba un buen español e, incluso, tenia buenos conocimientos de latín. Las primeras denuncias acerca de su existencia llegaron al recién instalado Tribunal del Santo Oficio en Lima hacia finales de los años setenta del siglo XVI. Se trataba de varias familias portuguesas acusadas de sacar la landrecilla de la pierna del carnero, un rito bien conocido por la Inquisición española, ya que todos los judaizantes por lo general lo practicaban.

La landrecilla es un tendón que se halla en medio del músculo del muslo del camero, y que está prohibido consumir según una antiquísima ordenanza bíblica en recuerdo de la herida que recibió el patriarca Jacobo en Penuel o Pnei El, esto es, "en el lugar en el que se manifestó el rostro de lo Sagrado". Alli, una noche, el patriarca Jacobo fue atacado por un ángel, o enviado de Dios, que lo hirió "en el encaje de su muslo", pero no pudiendo derribarlo lo bendijo, y cambió su nombre de Jacobo en Israel, cuya etimología explica la misma Biblia: "Porque has luchado con Dios y con los hombres y has vencido" acontecimiento es primordial en la historia hebrea porque significa el nacimiento del pueblo de Israel. Por tanto, se elimina la landrecilla del muslo de los cuadrúpedos, permitidos para el consumo humano, por la Ley de Moisés.

Incluso, algunos españoles de un remoto origen hebreo, después de vivir más de 120 años como cristianos, como lo era Alfonso de Rojas, nieto del famoso autor de la Celestina, natural del pueblo de Fonseca en el reino de Toledo, vecino de México, de 48 años de edad, médico cirujano con título por la Universidad de Salamanca, aún lo practicaban. Rojas era tenido por "cristiano nuevo", aunque él afirmaba que era "viejo". En 1604, fue acusado en el Santo Oficio de sacar "la landrecilla de la pierna del carnero", aunque nunca se procedió en su contra. En efecto, en abril de 1604, a raíz de la lectura del edicto de la Fe en la Iglesia Mayor, se presentó en el Santo Oficio Francisco de Santiago, de 34 años de edad, natural de Toledo, mercader de seda con tienda, amigo de Rojas, quien lo denunció a la Inquisición porque "...en el pasado verano sirvieron en su casa una pierna asada de cordero sin sacarle la landrecilla". Viéndolo "Rojas se enfureció con su esposa y presto tomó el cuchillo y con mucho cuidado la sacó y arrojó con ira". Santiago alegó que eso era una superstición de judios, a lo que Rojas respondió que era dañina y por eso él no la come. Otros cristianos nuevos, acusados por practicar el mismo rito, alegaban "que asi se asa mejor"si. Asimismo, Rojas también cultivaba la amistad de algunos cristianos nuevos e, incluso de los penitenciados, ya que salió en defensa de Marco Antonio, maestro de

49 Uchmany, "Los judios de Cochin" en Papeles de India, Consejo Indio de Relaciones Culturales, 1993, vol. XXII, num. 4, pp. 52-75.

50 Biblia: Génesis, cap. 32, versículos: 24-32.

s1 Véase en Uchmany, La vida entre el judaismo y el cristianismo en la Nueva España, 1580-1606, FCE y Archivo General de la Nación, México, 1992, reimpresión 1994, pp. 158-159. 
esgrima, penitenciado por el Santo Oficio con hábito y reclusión en la Cárcel Perpetua, que no podia abandonar desde el anochecer hasta la siguiente mañana. Además le fue prohibido practicar su profesión, asi que se mantenía vendiendo baratijas en la calle. Fue acusado por desacatos contra el Santo Oficio y lo salvó la enérgica defensa del cirujano. ¿Tendría el nieto del famoso escritor aún nexos sentimentales con la religión de sus ancestros?

\section{CRISTIANOS NUEVOS DE ORIGEN HISPANO-PORTUGUÉS EN AMÉRICA ESPAÑOLA}

Un gran número de cristianos nuevos, en su mayoria de origen portugués, incluyendo descendientes de hebreos que abandonaron la península ibérica, decidieron huir de la miseria de los ghettos desafiando las leyes que los excluyeron de la aventura americana. Alrededor de los años ochenta del siglo XVI, los encontramos en la Nueva España y una o dos décadas más tarde en el Caribe y en el Perí. Los primeros que regresaron a España fueron los hebreos que a raíz de la expulsión se refugiaron en Portugal, y en 1497 fueron obligados a bautizarse. Con el paso del tiempo varias familias e individuos aceptaron el cristianismo sinceramente y se integraron a la sociedad de los cristianos viejos. Sin embargo, la mayoria, aunque estaba forzada a asimilarse al modo de vida de los cristianos viejos, en su interior quedó apegada al judaísmo, que practicaba en la intimidad de sus hogares, a escondidas de vecinos y servidumbre que los podrian delatar. Por tanto la religión en la que creían con todo su ser y alma, y por la que se desvivian era para ellos un asunto netamente privado. Asi lo expresó la pequeña Ana de Carvajal en un día de 1595 , diciendo que van a la misa y se hincan y persignan y hacen otras ceremonias cristianas "para cumplir con el mundo". De aqui que diferían entre la religión que practicaban, que consideraban un acto privado y al cristianismo lo consideraban como un acto público y ciudadano. La actitud de diferenciar entre la religión nacional y el credo particular los convertía en los primeros hombres modernos. En suma, la religión oficial que estaban obligados a practicar fue tomada muy en serio por ellos mismos, ya que era parte de su vida pública.

Por ejemplo, Mariana de Carvajal, que deseaba estudiar, ingresó a los 14 años al Colegio de las Vizcainas, de donde la sacaron por la objeción de Gonzalo Pérez Ferro, primo de doña Francisca, su madre, a quien le reclamaba "que está poniendo a prueba un alma sensible" $\$ 2$, temiendo que podría abrazar el cristianismo. A pesar de la corta temporada que duró su escolaridad, Mariana se aprendió de memoria todos los salmos en latin y otras oraciones. Cabe subrayar, que la educación fue de suma importancia para los criptojudios, pues estaban apegados a una religión prohibida por el Estado y la Iglesia y repudiada por la sociedad en la que les tocó vivir. Pero, para vivir y sobrevivir debian conocer también el catolicismo no tan solo en teoría sino también en práctica, y en particular, las costumbres de la religión popular que podrían variar de lugar en lugar. Además era peligroso confiar en personas desconocidas, servidumbre e, incluso, de algunos parientes.

\$2 Uchmany, La vida entre..., p. 93. 
No es necesario decir que todo esto fue hecho en el mayor secreto posible, debido a que los criptojudios no estaban seguros ni en sus casas por los sirvientes, vecinos, compadres y amigos que los espiaban. Los periodos de la lectura de los Edictos de Fe exaltaron los sentimientos religiosos de la gente en general. Como católicos se sentían obligados a denunciar a cada uno que aparentaba herejía. En consecuencia, el precio que los criptojudíos pagaban por ser diferentes de la mayoría de la población y guardar su identidad viva, eran las cárceles secretas, tortura, confiscación de propiedades y otros procedimientos que transformaron a los ricos y poderosos en pobres y desamparados, todo esto, si no habían sido convertidos anteriormente en cenizas en uno de los Autos de Fe.

En su vida privada, por lo general los jueves en la noche mataban las aves que iban a consumir a usanza hebrea y las tapaban con una olla para que se desangrasen. Los viernes limpiaban la casa y cambiaban la ropa de la cama. En la víspera de la fiesta, las mujeres prendían velas y para no ser descubiertas las guardaban bajo la mesa. Rezaban en las noches después de retirarse la servidumbre. Los sábados, los hombres iban a trabajar como de costumbre, aunque la mayoría de ellos rezaban en sus trastiendas, con cabeza cubierta y con la cara hacia el Oriente, en dirección hacia Jerusalén. Las mujeres se quedaban en casa fingiendo que cosían o bordaban. Guardaban el sábado en la mejor forma que podian y así mismo las tres grandes fiestas anuales, el año nuevo y el día de la Remisión de los Pecados o Yom Hakipurim. Con mayor resplandor festejaban la Pascua del Cordero, enfatizando el concepto de la salida de Egipto, de la esclavitud hacia la libertad. Todos ellos tenían una fe inquebrantable en la venida del Mesías "aunque se tarde", como lo expresó el místico Luis de Carvajal durante su Segundo Proceso, quien luego fue entregado a las llamas en compañia de su madre, Doña Francisca, y cuatro hermanas en el auto de fe de la Cruz Verde, llevado a cabo en la Nueva España en 1596.

De aqui que aquellos que no aceptaron la imposición religiosa seguían siendo judios en ropaje de cristianos y deseaban que sus hijos continuasen su credo ancestral, y los seguían educando en la tradición de sus padres. Sin embargo, por el temor de ser descubiertos no les revelaban su identidad hasta la edad del entendimiento y su capacidad de guardar un secreto. En este caso, su propia religión les ayudaba, pues la mujer al llegar a los 12 años de edad está obligada a cumplir los Mitzwot, es decir, los preceptos de la Ley de Moisés. Los hombres se transforman en miembros de su comunidad un año más tarde. Antiguamente, incluso, los padres comprometían a los jóvenes en matrimonio a esa edad, aunque la boda se celebraba años más tarde.

Sin embargo, la doble educación llevaba consigo grandes peligros, pues la mayoría de los criptojudíos estudiaba en colegios católicos, y ocasionalmente algunos escogían una carrera eclesiástica aun antes de que sus padres se atreviesen a revelarles su identidad. Fue éste el caso de fray Gaspar de Carvajal, dominico, cuya familia arribó a la Nueva España en los años ochenta, y de muchos otros. Cabe mencionar que revelarle a un joven a la edad de los Mitzwot su identidad y obligaciones religiosas se consideraba una obra piadosa.

Por ejemplo, en una de esas revelaciones de identidad, participó Vicente Acosta, originario de Portugal, hombre cultísimo y políglota, pues además de portugués y castellano dominaba el hebreo así como el latín y el griego. Éste mercader y hombre de letras le reveló su identidad al joven Luis Díaz de Lucena. Acosta se había evadido de su país natal, con toda su familia, y se 
asentó en Flandes. Pero al no poder mantener a los suyos en Holanda, los dejó en Amsterdam en 1578 , y se embarcó a España. Hacia 1590 , ya tenía un barco y se dedicaba a mercar entre la Nueva España y el Caribe. En Cartagena se alojaba en la casa de Manuel y Luis Fernández Tristán, famosos mercaderes que albergaban a todos los cristianos nuevos que arribaban a este puerto. El cuñado de ambos, Luis Díaz de Lucena, quien vivía en aquel entonces con ellos, estaba por cumplir 13 años, edad en la que se convertiría en hombre adulto y debería cumplir con los preceptos religiosos, para lo que necesitaba una preparación intelectual y religiosa. Acosta se encargó de inmediato de enseñarle los preceptos de la ley.

Meses más tarde arribó a Cartagena Francisco López Enríquez, de 26 años, con mercancías que adquirió con el dinero que varias personas invirtieron con él. Era pariente de los hermanos Tristán y cuñado de Díaz de Lucena, a quien posteriormente le recordó "que le debía más a Acosta que a su propio padre, pues se atrevió a enseñarle "el camino de la verdad" ". El mismo Francisco López Enríquez era también un hombre cultísimo, pues su padre, Diego López de Lisboa, después de establecerse en Sevilla abrió una tienda en la calle de la Sierpe, en la que su esposa puso una confitería junto con sus hermanas. Por tanto tuvo los medios para procurar a su hijo una esmerada educación tanto judía como secular, pues lo hizo estudiar a lo largo de varios años en el Colegio de la Compañía de Jesús. De aquí que Francisco podia recitar largos pasajes de la Biblia, incluyendo Salmos, y transcribir oraciones en latín y castellano, que en ocasiones proporcionaba por escrito a parientes y amigos. En 1604 fue aprehendido en la ciudad de México por el Santo Oficio $y$, aunque según los inquisidores "sabia recitar noblemente la doctrina, sin embargo no supo a persignarse" ${ }^{33}$. Al respecto se podrían citar múltiples casos, incluyendo a mujeres.

En Cartagena de Indias la casa del médico cinjano, Blas de Paz Pinto, natural de Evora, servía regularmente de sinagoga. Así lo reveló la mulata Rufina a Diego López, mulato como ella, quien a pesar de ser casado mantenía relaciones sexuales con varias mujeres e, incluso con hombres en figura de enanos, preso a principios del año de 1634 por el Santo Oficio por practicar brujería en compañia de sus múltiples amigas. Era Rufina esclava de Clara Núñez, hija de una vasta familia criptojudía en la que abundaban los penitenciados por la Inquisición, incluyendo a su padre Domingo López y tío Luis Díaz, mencionados antes, quienes habían sido presos en el Tribunal de Lima entre los años de 1602 a $1606^{54}$. Rufina introdujo a Diego tanto en la brujeria como en los secretos de los criptojudíos cartagineses.

En efecto, en una tarde del año de 1629, llamó a Diego López, esclavo liberto, que anteriormente había servido en un hospital, a casa de Blas de Paz Pinto para que "...viese algo de aquello que leyan en las juntas que ella savia se hacian ocultamente en casa del dicho Blas de Paz Pinto,

53 Véase Uchmany, La vida entre el judaismo..., capitulo 5; "Proceso contra Francisco López Enriquez, portugués... por judaizante, México, 1601-1607", Caja fuerte de la Biblioteca Nacional de México, Archivo Franciscano, caja 66, exp. 1218.

54 "Testificación de Baltasar Araujo contra Luis Franco Rodriguez" en Manuel Tejado Fernández, Aspectos de la vida social en Cartagena de Indias durante el seiscientos, Sevilla, 1954, pp. $322-324$. 
unas veces de noche y otras a la hora de mediodia..." ${ }^{\text {"5s. }}$. Como a las cinco de la tarde, asomado de la ventana de Martín Sánchez, boticario ${ }^{56}$, Diego, "*...vio salir de casa del dicho Blas de Paz como diez hombres, más o menos, y solo se acuerda de aver conocido dos de ellos, que el uno fue, Juan Rodríguez Mesa, portugués... y el otro...fue, un fulano Núñez, de oficio cirujano, de nación portugués y deudo de Clara Núñez, el cual suele asistir en la villa de Monpox..." ${ }^{\text {"7 }}$. En otra ocasión los mulatos deseaban saber lo que se leía en aquellas reuniones y, aunque Diego López “...se arrimó a una ventana todo lo que pudo y oyó a una persona que hablaba haciendo pausa en voz baxa y nunca pudo entender ni percibir razón alguna..." "sp. Otro día Rufina le enseñó incluso al hombre que conducía los rezos, en aquella sinagoga improvisada, que en hebreo se llama Hazan. Era éste "...un mozo de buena persona, que yba de casa del dicho Blas de Paz por la calle abaxo, el cual era moreno de rostro y no tenía barbas, porque sería hombre al parecer de veynte y tres o quatro años, de nariz larga y el cavello negro y con una media sotanilla y sin espada" 59 . Rufina y Diego no entendian la lengua de las oraciones, lo que sugiere que rezaban en hebreo. En efecto, el cirujano Paz de Pinto juntó en su casa un minyan o diez hombres, número necesario para que un grupo se transformase en comunidad y se pudiesen efectuar servicios regulares e, incluso, leer la Torah, o sea, el Pentateuco. Por cierto, la congregación se reunía en ocasiones en la tarde para la oración de la Minkha (oración al atardecer) y algunas veces a la hora del crepúsculo para el servicio del Maariv (oración al anochecer). Las plegarias de la mañana, o sea el Shakharit, rezaban estos hombres, en la medida en que las circunstancias se los permitian, en la intimidad de sus casas. Como se ha visto en las oraciones comunales los criptojudios se organizaban para rezarlas por lo general en conjunto, tanto en Cartagena, como en la Nueva España y el Perú.

Cabe mencionar que varios judios llegaban a las costas americanas de Italia, Francia e incluso de Holanda y otros rincones de Europa; uno u otro qurioso logró cruzar los Balcanes, pues los vientos de la Contrarreforma que soplaban en los países católicos los obligaban a vivir en estrechos barrios. Muchos cristianos nuevos tenían parientes y amigos asentados en Filipinas, al servicio de la corona portuguesa, e incluso fueron a negociar a los dominios lusitanos en el Sureste Asiático. También hacian viajes de negocios a Japón y China, como lo hizo Diego de Almeida en los años ochenta del siglo XVI.

La presencia portuguesa y la abundancia de piratas, sobre todo de origen inglés que amenazaban las costas americanas desde la mitad del siglo XVI, molestaba a la Corona. A la vez se generaron

"Testificación de Baitasar Araujo contra Luis Franco Rodríguez" en Manuel Tejado Fernảndez, Aspectos de la vida social en Cartagena de Indias... p. 200.

"Testificación de Baltasar Araujo contra Luis Franco Rodriguez" en Manuel Tejado Fernández, Aspectos de la vida social en Cartagena de Indias durante el seiscientos, Sevilla, 1954, pp. $322-324$.

"Testificación de Baltasar Araujo contra Luis Franco Rodriguez" en Manuel Tejado Fernández, Aspectos de la vida social en Cartagena de Indias durante el seiscientos, Sevilla, 1954, pp. 322-324.

"Testificaciỏn de Baltasar Araujo contra Luis Franco Rodríguez", en Manuel Tejado Fernández, Aspectos de la vida social en Cartagena de Indias durante el seiscientos, Sevilla, 1954, pp. 322-324,

"Testificación de Baltasar Araujo contra Luis Franco Rodríguez", en Manuel Tejado Fernández, Aspectos... p. 200. 
muchas quejas sobre portugueses sospechosos en materia de fe y piraterias. A estas quejas se aunaron las denuncias de los frailes sobre la disolución moral en las Indias, lo que impulsó a Felipe II a tomar cartas en el asunto. Abolió la Inquisición Primitiva o Apostólica integrada por frailes y obispos y estableció el 25 de enero de 1569 el Santo Oficio en América. El primer Tribunal se introdujo en 1570 en Lima, Perú, y el segundo se estableció en la ciudad de México con jurisdicción sobre Filipinas. En 1610, se formó un tercer tribunal en el puerto de Cartagena de Indias. Los inquisidores empezaron inmediatamente a trabajar. En 1569 se publicó el primer Edicto de Fe en todas las iglesias, por medio del que se exhortaba a la población a denunciar a todos aquellos que hubieran ofendido las normas católicas de vida y comportamiento. La lectura dio como resultado un sin número de acusaciones contra blasfemos, bigamos, frailes libertinos, luteranos, calvinistas y judaizantes.

Muchos criptojudíos, después de vivir en Portugal como cristianos y de haberse beneficiado del comercio marítimo, encontraron muy difícil acostumbrarse a la vida de los barrios judíos y guettos. Los más osados, con la esperanza de hacer una pequeña fortuna y poder volver algún día a Italia, Holanda, Turquía o algún lugar donde pudieran ejercer su fe, se lanzaron a los territorios españoles arriesgándose a la persecución del Santo Oficio. La coerción religiosa los obligó a vivir como cristianos, aunque en los guettos podían vivir como judíos. Por ejemplo, Diego Pérez de Alburquerque, nacido en Bordeaux, fue educado en Ruen, llegó a la Nueva España en 1518, y vivió en Puebla, la ciudad de México, y después se asentó en el centro minero de Zacatecas. Álvaro Méndez, preso en 1561 en Lima, vivió anteriormente en Francia, y enviaba dinero a su familia desde Perú a Amsterdam. Julián Álvarez llegó a México de Holanda; fue penitenciado en su ausencia por el Santo Oficio, ya que tuvo la suerte de escapar a buen tiempo. Luis Franco Rodríguez, residente en Cartagena de Indias, tenía hermanos en Holanda y, a lo largo de su vida, tenía la esperanza de vivir una vida confortable con su familia como judío. Isabel Núñez, que vivía con su esposo en México, nació en Francia. Su hermano, Enrique Núñez Espinoza residió con su esposa, doña Mencia de Luna, en Lima. Ella murió después de ser brutalmente torturada por el Santo Oficio del Perú, sin denunciar a alguien. Otro caso es el de Juan Rodriguez de Silva quien habia vivido en Francia, Italia y el Imperio Turco. Se casó en Salónica, donde había dejado a su esposa y viajó una vez más a Italia, y de ahi a España, donde se embarcó a las Indias. Huyó de Nueva España cuando los oficiales de la Inquisición lo buscaban. Por ello, fue quemado en efigie, como lo hacian con personas ausentes, en el Auto de Fe celebrado en la ciudad e México en 1596. Jorge de Almeida, amigo de Silva, vivió en Ferrara hasta la década de 1570, y al empezar los problemas económicos en el ducado a causa de las guerras con los turcos, partió a la Nueva España con su familia. Su prima, Blanca Lorenza, se asentó en Sevilla y abrió una posada donde muchos criptojudios se detenían en su camino a las Indias; a ellos les servia comida Kosher. Almeida, quien huyó de México en 1590, después de que el Santo Oficio prendió a su esposa, sobrina del gobernador del Nuevo Reino de León, don Luis de Carvajal y de la Cueva, tenía buenos abogados en Madrid, que le ayudaron a negociar no tan solo la absolución de los 
hábitos penitenciales de los Carvajal, sino que le consiguieron también dos pasaportes a dos judíos portugueses que vivian en Italia, Ruy Diaz Nieto y|su hijo Diego ${ }^{60}$, nacido en Ferrara.

Muchos otros criptojudios perdieron la habilidad de echar raices en cualquier lugar y por tanto se trasladaban a lo largo de su vida de un lugar a otro. Ese fue el caso de Baltasar de Araujo, descendiente de Abraham Senior, Rabino Mayor de Castilla, proveedor de armas de los Reyes Católicos en la conquista de Granada, y uno de los más fíleles consejeros de Isabel. Por estas razones, después de firmar el Edicto de la Expulsión de los Judios el 31 de marzo de 1492, la Reina Católica hizo lo posible para conservar a su antiguo servidor. La única forma de conseguirlo fue obligarlo a bautizarse. Durante la ceremonia, Senjor y su familia tomaron el nombre de Pérez Coronel. Cuando el Santo Oficio prendió a Baltasar en Cartagena de Indias y le preguntaron por su nombre les respondió: "aquí me llaman Araujo, pero mi sobrenombre es Coronel, de los Coroneles de Galicia”. También dijo que su familia se refugió en Portugal por miedo al Santo Oficio, luego volvieron a España y se asentaron en Galicia. En esta provincia, el Tribunal de la Inquisición fue formalmente establecido en 1562 y comenzó a funcionar en 1574. Por estas fechas, la madre de los Araujo Coronel se embarcó con sus ocho hijos a casa de unos parientes en Flandes. De ahí pasó a Venecia donde todos sus hijos fueron circuncidados y recibieron nombres hebreos. Baltasar fue llamado Abraham Senior por su ilustre antecesor. Inmediatamente comenzaron a estudiar el judaísmo, se trasladaron a Salónica y luego a Constantinopla. Parte de sus hermanos se establecieron en Cairo y luego en Alejandria. Algún tiempo más tarde, Baltasar quería visitar su país natal, llegó a Bayona, pero no se atrevió a entrar a España por temor al Santo Oficio y, finalmente, regresó a Constantinopla. Sin embargo no aguantó el deseo de "ver el mundo" y, por tanto, cruzó los Balcanes y viajó a ltalia, España y se embarcó a las Indias.

Viajeros como Coronel-Senior, infundieron una nueva vida en las pequeñas comunidades criptojudías en América y los mantenían en contacto con los centros intelectuales del judaísmo. Ocasionalmente, estos hombres como, por ejemplo, Juan Pacheco de León, que vino a México en 1639 de Livorno, Italia, se transformaron en guías espirituales para ciertos grupos de sus correligionarios. Aun más, todos estos judíos llevaban cons.go libros impresos en Ferrara, Venecia y otros centros culturales, que llegaron junto con ellos no tan solo a la Nueva España sino a los lugares más remotos del Imperio Español como Filipinas, Macao, Malaca, Cochin y Goa. Manuel de Paz, de 34 años, preso en Lima en 1634, tenía una de esas Biblias. El médico Blas de Paz Pinto, que convirtió su casa en Cartagena de Indias en una sinagoga, poseía no solamente una Biblia en hebreo sino también un libro de rezos o Makhzor. De éste leía uno de los miembros de la comunidad, al atardecer, el pasaje apropiado a una audiencia de diez o más hombres que se juntaban para el rezo del atardecer o Maariv. En 1637, Simón Váez Sevilla fue denunciado por su compadre, Pedro de Navia, por tener abierta una de estas Biblias en su escritorio. Algunos otros fueron acusados por la misma causa ${ }^{61}$. Fue aprehendido el 20 de junio de 1642 , por encabezar una pequeña comunidad hebrea en la Nueva España.

60 Véase Eva Uchmany, La vida entre... p. 41.

63 Eva Alexandra Uehmany, "Simón Váez de Sevilla", en Estudios de Historia Novohispana, Vol. 9 No 8, México, Instituto de Investigaciones Históricas, 1987. 
Durante el periodo de la Corona Unida la mayoría de los criptojudíos trató de curnplir con los mandamientos de la Torah. Todos ellos observaban el Sabbath, aunque los hombres acudian a sus trabajos, para no llamar la atención. Para las mujeres era más sencillo pretender que estaban cosiendo o bordando sin estar haciendo nada. Un número importante de ellos se abstenia de comer alimentos prohibidos, sin embargo servían tocino y jamón cuando tenían visitas. Según lo permitieran las circunstancias, celebraban las tres fiestas anuales, Pesah, Shavuot y Sukkot. Además, ayunaban estrictamente en el Día Grande del Señor o Yom Hakippurim, y en el Taanit Esther (el ayuno de Esther). Debido a la opresión religiosa en la que vivían, la Reina Esther era considerada como una de las más grandes heroínas hebreas, pues ella había salvado a su nación de la destrucción. Muchos criptojudíos ayunaban lunes y jueves, días en que se leia la Torah en las sinagogas. En las visperas y al finalizar los ayunos, cenaban platos frugales como vegetales, fruta, pescado, huevo y queso. En estos banquetes, un pequeño grupo de amigos se juntaba para discutir la ley de Moisés. En el Kippur, después de la cena, rezaban a lo largo de toda la noche. El siguiente día, algunos se iban al campo para que la gente no notase su ayuno. Al anochecer volvian a sus casas para romper el ayuno en compañia de familia y amigos. En estas reuniones se reiteraba que uno se puede salvar solamente por medio de la Ley de Moisés. Además en estas ocasiones, aquellos que alguna vez vivieron en algún barrio judio en Europa, relataban sus experiencias de aquellos días. En todas estas reuniones surgía el tema del Mesías, ya que cada uno de los presentes añoraba la pronta e inmediata redención de Israel. Algunos incluso, como Manuel Díaz, quemado en el Auto de Fe de la Cruz Verde, llevado a cabo en la Ciudad de México en 1596, predecian la fecha de su llegada. Díaz calculaba que el Mesías llegaría el año de 1600. Durante su prisión Manuel soñaba que el Ungido de la Casa de David abría las cárceles secretas del Santo Oficio. Viéndose libre en la calle, pasaron algunos conocidos a los que dijo: "¡Vean! Dios está defendiendo su causa..." Otros creían que el Salvador nacería en una familia criptojudía. En 1620, siendo preñada Juana Enríquez con su hijo Gaspar, se creía que ella daría a luz al Salvador porque observaba estrictamente todas las ordenanzas y porque su marido Simón Váez ${ }^{62}$ era descendiente de la tribu de Leví. Cuando Gaspar no resultó ser el Salvador, se creía que podria nacer en otra mujer de la comunidad. Cada cosa irregular y extraña que sucedia, era vista como el signo de su llegada. Gente simple, así como la educada, creía con toda su fe que Dios no habia abandonado a su pueblo. Gracias a esta profunda fe, que al mismo tiempo era una ideologia futurista, los sobrevivientes a los Autos de Fe de esta época, en los que algunos miembros de sus familias o amigos fueron eliminados en el quemadero, tenían la fuerza y energía para educar a sus hijos en su credo ancestral.

La intensa actividad del Santo Oficio y los Autos que se celebraron entre los años de 1570 a 1640, en los virreinatos del Perú y la Nueva España, casi borraron del mapa del Imperio Español a las pequeñas comunidades hebreas que se habian asentado desde la segunda mitad del siglo $\mathrm{XVI}$ en ellas.

62 Eva Alexandra Uchmany, "Simón Vaez Sevilla" en Michael the diaspora research Institute. Tel Aviv University... 1983, vol 8 p. 145. 
Un gran número de hombres fue enviado a las galeras por periodos de cinco a diez años. Eso significaba una muerte segura ya que nadie sobrevivia a vivir en su propio excremento, tomar agua dulce solo si sobraba de los marineros, más de dos años. Aquellos que por algún milagro sobrevivieron, una vez liberados tenian que comenzar todos desde cero, pues toda su propiedad había sido confiscada. Así, que el Santo Oficio no les dejaba otra alternativa que pedir limosna en las calles, que era su deseo y finalidad.

Muchos de los hijos de familias hebreas salían de sus casas a edades muy tempranas con parientes que los introducían a diversos cargos y negocios que estaban a su alcance. Uno de ellos fue Luis de Carvajal y de la Cueva, conocido como el Viejo, para distinguirlo de su sobrino, el Mozo, originario de Mogodorio, en la Raya de Portugal. Nacido en el seno de una familia de cristianos nuevos ${ }^{63}$, a los 10 años de edad se fue con su tío Duarte de León, factor del rey de Portugal a las islas de Cabo Verde, donde fue empleado como contador. A los 22 años regresó a España y se casó con Guiomar de Rivera, hija de Miguel Núñez, factor de la Corona de Portugal en Santo Domingo. La pareja convivió solamente dos años, pues don Luis era cristiano sincero y devoto de la Virgen y doña Guiomar, judía practicante que sacrificó su vida matrimonial por su religión. Carvajal se embarcó por vez primera a la Nueva España hacia finales de 1566 como almirante de la flota en la que viajaba el virrey don Martin Enriquez de Almanza (1567-1570). Llegando a Jamaica, en vista de que el puerto estaba en manos de corsarios ingleses, don Luis se adelantó con su gente en el batel y logró atraparlos. Luego tomó el camino hacia el norte de México donde participó en la conquista y pacificación del Nuevo Reino de León, atrapando a cerca de 100 piratas de la armada de John Hawkins. Cuatro años más tarde fue nombrado gobernador de este reino por recomendaciones del mencionado virrey. Luego regresó a España por su esposa, que se negaba a acompañarlo. Por tanto trajo consigo a su hermana y su familia. Posteriormente comenzó a sospechar que la familia de ella era judaizante, lo que le causó terrible pena, y se separó de ellos. En vista de ello, Doña Francisca y su familia, se trasladaron a la ciudad de México, dedicándose los hijos a llevar mercancía a las minas. Pronto se relacionaron con otros criptojudíos y su casa se volvió el centro de la comunidad hebrea, siendo el carismático Luis de Carvajal, el Mozo, el hombre más admirado. La familia planeaba traşladarse en algún momento a Italia, para poder practicar su fe libremente e incluso emigrar a Jerusalén, en donde tenían la esperanza de poder vivir libremente como judios. En efecto, la mayoria de los criptojudíos procuraba cumplir con los mandamientos y preceptos estipulados en los cinco libros de la Ley de Moisés. Todos guardaban de alguna forma el sábado, que comienza a festejarse en la noche del viernes después de la caida del sol. De aquí que muchos grupos se congtegaban en la víspera del día festivo en cierta casa para rezar y cenar juntos.

En 1589, el Santo Oficio apresó a Doña Francisca junto con su hijo Luis y sus tres hijas mayores Isabel de Andrada, Catalina de León y de la Cueva, esposa de Antonio Díaz de Cáceres, y Leonor de Carvajal, mujer de Jorge de Almeida. Dos hijos de la familia, el mayor Baltasar

Alfonso Toro, La famitia Carvajal, estudio histónico sobre los judios y la Inquisición de la Nueva España en el siglo XVI, basado en documentos originales y en su mayor parte inéditos, que se conservan en el Archivo General de la Nación de la Ciudad de México, México, Patria, 1944. Tomo I. pp. 25-41. 
Rodríguez, y el menor, Miguel de Carvajal, lograron evadir la prisión y huir de la Nueva España. Mientras tanto, las mujeres de la familia fueron reconciliadas el 24 de febrero de 1590 , en el auto de fe llevado a cabo en la Catedral de la Ciudad de México. En el mismo acto, doña Leonor, doña Catalina y doña Mariana Núñez de Carvajal, fueron condenadas con cárcel y hábito penitencial por un año, y doña Francisca, la madre de todos ellos, Isabel de Andrada y su hermano Luis fueron sentenciados con hábito y cárcel perpetua, irremisible. A todos ellos les fueron confiscados sus bienes.

La primera denuncia contra los Carvajal se originó aún estando en Tampico, tratando Isabel de Andrada de cumplir la promesa dada en España a doña Guiomar, la esposa del Gobernador Carvajal de convertir a su marido y a su sobrino, Felipe Núñez, al judaísmo. La viuda trató de acercarse al último, quien por entonces ya odiaba a la familia de don Luis, pues antes de su llegada se consideraba su heredero y ahora se sentía despojado de sus derechos. Por tanto estaba decidido a denunciarlos por judaizantes. Siete años más tarde, Felipe Núñez vino a la ciudad de México y denunció a toda la familia de doña Francisca por judaizantes y a don Luis de Carvajal y de la Cueva como su encubridor. En 1589, todos ellos estaban encerrados en las cárceles secretas de la Inquisición y el gobernador en la cárcel de la Corte, en la que murió un año más tarde, tanto por su quebrantada salud como de tristeza. Así terminó sus días el pacificador y fundador del Nuevo Reino de León. Debido a las circunstancias en las que acabó sus días, la Historia jamás reivindicó su valentía, esfuerzos y honestidad. Aun más, aquellos que jamás se acercaron a las fuentes documentales le inventaron que mercaba con esclavos y semejantes, actos que le eran ajenos y le repugnaban.

Por su parte, Jorge de Almeida, esposo de Leonor de Carvajal, quien después del proceso de su esposa se fugó con su hermano a España, después de tres años y medio de cansados trámites, con la ayuda de importantes cristianos nuevos como lo eran Antonio Rodríguez de Escarigo, procurador de causas y el doctor Váez, uno de los médicos de cabecera de Felipe III, cristiano nuevo, obtuvo del Consejo de la Suprema Inquisición no tan solo la remisión de los hábitos penitenciales de toda la familia, sino también su total rehabilitación en el seno de la Iglesia.

Poco tiempo después de la absolución, Luis Carvajal fue inculpado por su gran amigo Manuel de Lucena, preso por las acusaciones de su primo Domingo Gómez Navarro, cristiano sincero, a quien quería volver al judaismo, cuando se encontraba enfermo. Lucena, torturado a lo largo de varios días en el potro, mencionó a Luis de Carvajal, quien unas semanas más tarde fue también preso en las cárceles secretas. Desde un principio declaró que quería morir como judío, sin embargo, el Santo Oficio buscaba testimonios, que obtuvo mediante tortura. Luis de Carvajal, después de horas de tortura testificó contra toda su familia, amigos y conocidos. Los inquisidores lo tuvieron desnudo y tendido en el potro durante cuatro días involucrando a toda la comunidad judía de la Nueva España.

El 8 de diciembre de 1596, día de la Inmaculada Concepción, se celebró en la Ciudad de México el famoso Auto de fe de la Cruz Verde, primero en llevarse a cabo en esta Ciudad. En este Auto desfilaron 69 reos de los cuales 47 eran judaizantes u observantes de la Ley de Moisés. De los judaizantes, abjuraron de levi 8 y de vehementi 16 . 
Fueron relajados al brazo secular, es decir, quemados, 9 reos, entre ellos toda la familia Carvajal, salvo Mariana, Ana, la hermana más pequeña, y la hija de Catalina, Leonor de Cáceres, junto con Manuel Lucena, Manuel Díaz y Domingo Rodriguez. Ocho reos fueron relajados en estatua por ausencia y fugitivos, y otros 2 , relajados en estatua y huesos por ser difuntos. Cuando se apagó la última antorcha humana, la Ciudad de México fue alumbrada festivamente con todas las luces y se inició una fiesta porque la fe había vencido a la herejía.

El 4 de diciembre de 1600 fue aprehendido Antonio Diaz de Cáceres, y Mariana de Carvajal quien vivía en su casa después de la muerte de su esposa. Fue depositada en casa de Doña María de Peralta, madre de Bernardino Vázquez de Tapia, miembro de la oligarquia novohispana y familiar del Santo Oficio. En este su "nuevo hogar" encontró la paz y calma necesarias pues, hacia finales del siglo, en 1601, recuperó la razón. Sus benefactores la convencieron de que sanó el día de la Concepción gracias a la intervención de la Virgen María. Doña Mariana creyó en este milagro con todo su ser y alma. Los inquisidores, que le perdonaron la vida en 1596, esperaron durante todo este tiempo con paciencia para que recuperase su lucidez. Después que ocurrió el milagro, la apresaron por relapsa y reincidente. Durante su segundo proceso como cristiana sincera que entonces ya era, hizo una confesión amplia y llana y, en consecuencia, denunció a muchas personas. A pesar de ello fue condenada y relajada al brazo secular. Fue éste el modo como el Santo Oficio interpretaba la justicia cristiana. Además se actuó con ella misericordiosamente, pues antes de ser entregada a las llamas fue ahogada con el garrote. Testificó contra su hermana menor, Ana de León, y contra su sobrina, Leonor de Cáceres, que con ocasión del Auto de 1596 fueron depositadas en casas de reconocidas matronas desde donde fueron traídas a las cárceles secretas del Santo Oficio en la primavera de 1600.

Fue Mariana la que hizo saber a los inquisidores que los Díaz Nieto eran originarios de la judería de Ferrara y que, amparados por una bula papal conseguida por medio de una falsa relación, se ganaban la vida recolectando limosna. Ana y Leonor se vieron obligadas a confirmar esta testificación al igual que las declaraciones de Mariana contra Antonio Díaz de Cáceres. El 10 de enero de 1601, Diego Díaz Nieto fue acusado formalmente de reincidente, encubridor de herejes, y de haber visitado las juderías en Italia. Diego contestó que el no era cristiano bautizado sino judío circuncidado, nacido en Ferrara y les contó la causa de su viaje a la Nueva España. Aunque el Santo Oficio no juzgaba a judíos sino solamente a cristianos bautizados que apostataban, los judios tenian prohibida, so pena de muerte, la entrada a los territorios del Imperio español, desde el día 31 de agosto de 1492, fecha de su expulsión de España. Además le preocupaba su padre, cristiano bautizado, que abandonó Portugal cuando niño en compañia de sus progenitores.

El Auto de Fe de 1601 era el más grandioso que se había celebrado hasta entonces en la Nueva España; se inició en las vísperas de la fiesta con una solemne procesión, desfilando por las calles de México con cirios encendidos alrededor de mil personas, entre los diferentes oficiales del Santo Oficio, caballeros y órdenes religiosas. Al dia siguiente la procesión que incluía a los reos, 124 vivos, 19 estatuas y 3 cajones de huesos, salió del edificio del Tribunal a las seis de la mañana. La lectura de las causas se inició a las 8 de la mañana. Entre los herejes se encontraban luteranos, calvinistas y 43 judaizantes. De ellos, 21 abjuraron de vehementi, de los cuales se condenó a 5 a galeras. Abjuraron de levi, solo 4 reos. Fueron relajados al brazo secular dos reos en persona, 13 fugitivos quemados en estatua y 3 difuntos quemados en estatua y huesos. 
El destino de los criptojudíos que se asentaron en la América española en las tres primeras décadas del siglo XVII, era similar al destino de sus hermanos en el siglo XVI. La diferencia era que a pesar de la depresión económica que sufrían los dominios españoles en el siglo XVII, un buen número de cristianos nuevos logró enriquecerse. Su origen portugués, así como sus fortunas, provocaron envidia y celos entre los oficiales reales. El gobernador de Panamá, Francisco Valverde Mercado, expresó el sentimiento de muchos cuando escribió a Felipe II que "hoy los mercaderes de las Indias son de los portugueses porque ellos tienen el contrato de abasto de esclavos... y del despacho de flotas y escuadrones en un buen día del cual depende todo negocio... y... de esta nación ha habido por aquí muchos mercaderes judíos que viven bajo su Ley y que, una vez enriquecidos, parten a otros reinos antes de caer en manos de la Inquisición" ${ }^{64}$. Un mes después avisó al rey, que había tenido informes que muchos de ellos se habian ido a Roma, Venecia, Ferrara y otros lugares.

En la Nueva España, en los años treinta del siglo XVII, la familia Silva-Carvalho ${ }^{65}$ solía festejar el dia del sábado en la casa de Isabel hija de Gómez da Silva y de su esposa Elena, naturales de Castelo Blanco en Portugal. Los Carvalho o Carvallo, asi como sus contemporáneos, la familia de Simón Váez Sevilla, preparaban el viernes los alimentos que iban a consumir el sábado y, en estos días, se rehusaban a recibir visitas de extraños. Esta conducta los hizo sospechosa a los ojos del maestro sastre Manuel Viscarreto, alias Luis Carreto, quien antes de venir a la Nueva España había vivido en Italia y estaba familiarizado con costumbres judaicas. El sastre, en compañia de su oficial Luis Aguilar, espió a lo largo de seis años tanto a los Silva-Carvalho como a los Váez Sevilla y a todos sus amigos y parientes. Luis Carreto incluso llevaba un "Diario" en el que anotaba que los Silva-Carvalho no comían jamón ni tocino y no guisaban con manteca sino con aceite de ajonjolí; incluso, en ocasiones, cuando doña Elena iba al mercado Carreto la seguía, pues anotó en su "Diario" que fingía que estaba comprando jamones y longanizas o tocino, pero, buscando cualquier pretexto, jamás los adquiría; que reñía con sus negros cuando compraban la parte trasera de la res y otros detalles de su vida. Finalmente, con deliberada intención entregaba a sus clientes judíos los sábados la ropa que les cosía, a sabiendas de que se negarían a pagarle de inmediato, pues en este día no tocaban dinero.

Sin duda, muchos criptojudíos que llegaron a la Nueva España se fueron, pero otros se quedaron y sus fortunas no fueron a dar a otros reinos, sino a las arcas del Santo Oficio. Al respecto podemos mencionar el caso de Manuel Bautista Pérez, minero y comerciante en el Perú, que se enriqueció comerciando tanto con esclavos negros como con especias y además, tenía tratos con la India. Era, al mismo tiempo un intelectual, que poseia una notable colección de pinturas y una buena biblioteca de alrededor de 150 volúmenes. El inventario de su biblioteca cuenta con novelas, libros de historia, derecho, filosofia, relatos de viajes de los siglos XV y XVl y semejantes, además de veinticinco libros de tratados religiosos, entre los que destacaban libros de hagiografía, sobre el culto mariano, la vida de Cristo, y Tratados sobre la comunión de Fernando Quirino

64. AGN Inquisición Vol. 30 Exp. 5.

65 Alexandra Uchmany, "Simón Vaez Sevilla" en Michael The Diaspora Research Institute, Tol Aviv University... 1983, vol 8 p. 144. 
de Salazar, publicado en Madrid en 1622, un libro del dominico fray Blas de Acosta. En total, eran libros cristianos que diferian tajantemente de la religión hebrea, que explicaban dogmas como la Trinidad, el culto a la Virgen, la encamación de Cristo, y semejantes. Así, Pérez tenía libros de interés general, especialmente los libros de viaje, que quizá alimentaban su interés por buscar nuevos horizontes. Además, los libros religiosos tan ajenos a la religión judia sin duda los exhibía frente a sus clientes y otros visitantes que pudieran cuestionar su fe. En algunos de ellos se criticaba obviamente a la "caduca Ley de Moisés" que quizá como cristiano nuevo en ropaje de cristiano viejo debia conocer. Es necesario subrayar que los cristianos nuevos que vivian en la segunda mitad del siglo XVII, en muchas ocasiones, asimilaron también formas del cristianismo, ya que estaban obligados a vivir como cristianos ciento cincuenta años, que en muchos dejaron huellas en formas e ideas, influían su pensamiento y quehacer cotidiano, aunque no siempre rompieron los lazos con su origen, a pesar de que quienes tuvieron buena suerte y lograron regresar a alguna judería recuperaron el antiguo modo de creer y vivir, es decir, lograron integrarse a la comunidad de ella. Sin embargo, muchos de ellos no lograron integrarse en las comunidades hebreas de origen ibérico, por el largo tiempo alejados del modo de vida judía, que era mucho más rigurosa, y limitante para algunos, asi como les era dificil adaptarse a la dieta hebrea que prohibia comer todos los animales que no rumian, después de acostumbrarse a comer diferentes cames y embutidos en el Imperio Español. A su vez, también era dificil acostumbrarse a la forma de pensar, en condiciones que obligaron a un Benito Baruj Espinoza a vivir en su propia soledad.

\section{BIBLIOGRAFIA}

ASHTOR, Eliyahu

The Jews of Moslem Spain

Philadelphia, The Jewish Publication Society of America, 1973. v. 1.

BEINART, Haim

Records of the Trials of the Spanish Inquisition in Ciudad Real

The Israel Academy of Sciences and Humanities, Jerusalem, 1974, 1977, 1982, 1986. 4 vols.

BOYD-BOWMAN, Peter

Léxico hispanoamericano del siglo XVI

Londres, Tamesis Books Limited, 1971.

BONILLA, Licenciado, secretario del Tribunal del Santo Oficio en la Nueva España Diligencias sobre los Sanbenitos antiguos y renovación de ellos, y postura de los que se han relaxado y requerido por este Santo Oficio, México, 1574 Archivo General de la Nación de México Inquisición, v. 77 , exp. 35-63 f (redactó dicho texto para que los sambenitos recuerden los nombres de los herejes condenados por el primitivo Tribunal del Santo Oficio para la eternidad).

CANTERA Burgos, Francisco

Abraham Zacut

M. Aguilar, M. Madrid, S A., 1950. 
"Cartas dirigidas al Santo Oficio desde Mérida Yucatán", 1575, AGNM, Inquisición, vol. 79, exp. 10 ; vol. 80 , exps, $8,10,11,21$. Año 1579.

CASAS, Fray Bartolomé de las

Historia de las Indias

Estudio preliminar por Lewis Hanke, Fondo de Cultura Económica, México, 1965, vol. I.

CASTRO y Tosi, Norberto

"Verdadera patemidad de Alonso de Estrada"

En Revista de Indias, Madrid, 1948, vol. 9.

COHEN, Jeremy, editor

Essential Papers on Judaism and Christianity in Conflict; From Late Antiquity to the Reformation

New York University Press, 1991.

COLÓN, Cristóba]

Los Cuatro Viajes del Almirante y su Testamento

Edición y Prólogo de Ignacio B. Anzoátegui, $4^{\mathrm{a}}$ edición

Espasa Calpe, Madrid, 1964, Colección Austral.

DAVID, Abraham

To Come to the Land. Immigration and Settlement in Sixteenth-Century Eretz-Israel

The University of Alabama Press, Toscaloosa \& London, 1999.

DOMINGUEZ Ortiz, Antonio

La clase social de los conversos en Castilla en la Edad Moderna

Introducción por Francisco Márquez Villanueva, semblanza del autor por Luis J. Coronas, Universidad de Granada, 1991.

DOMINGUEZ Ortiz, Antonio

Los judeoconversos en España y América

Ediciones Istmo, Madrid, 1971.

DE LOS RIOS, José Amador

Historia social, politica y religiosa de los judios de España y Portugal

Aguilar, Madrid, 1960.

EIDELBERG, Shlomo, traductor y editor

The Jews and the Crusaders; The Hebrew Chronicles of the First and Second Crusades

The University of Wisconsin Press 1991.

FERNÁNDEZ del Castillo, Francisco

"Alonso de Estrada y su familia"

En Memorias de la Academia Mexicana de la Historia

México, 1942, T. 1, pp. 398-431. 
GARCIAA ICAZBALCETA, Joaquín

Colección de documentos para la historia de México

Porrúa, México, 1971, T. 1.

GUILLÉN, Claudio

"Un padrón de conversos"

En Bulletin Hispanic, 1963, t. 65.

HEMMING, John

The Conquest of the Incas

Macmillan \& Co, Londres, 1970.

LAEUCHLI, Samuel

Power and sexwality, the emergence of canon law at the synod of Elvira

Philadelphia, Temple University Press 1972.

LOHMAYER, Gudrun

Génesis histórica de Chiapas 1522-1532. El conflicto entre Portocarrero y Mazariegos

Instituto de Investigaciones Filológicas, UNAM, México, 1993.

MILLARES Carlo, A. y J. I. Mantecón

Índice y extracto de los Protocolos del Archivo de Notarias

Colegio de México, México, 1945, t. I.

MARCUS, Ivan G.

"From Politics to Martyrdom: Shifting Paradigms in the Hebrew narratives of the 1096 Crusade riots". En Cohen, Jeremy, editor, Essential Papers on Judaism and Christianity in Conflict; From Late Antiquity to the Reformation

New York University Press, 1991.

OTTE, Enrique

Las perlas del Caribe: Nueva Cádiz de Cubagua

Fundación John Bulton, Caracas, 1977.

"Proceso contra Juan Fernández del Castillo por blasfemo"

México, 1536, AGNM, Inquisición, vol. 14, exp. 14.

PORRAS Muñoz, Guillermo

El gobierno de la Ciudad de México en el siglo XVI

México, Instituto de Investigaciones Históricas, UNAM, 1982.

PIKE, Ruth

Aristócratas y comerciantes: la sociedad sevillana en el siglo XVI

Barcelona, Ariel, 1978. 
"Proceso contra Diego Núñez por blasfemo", México, 1527, AGNM, Inquisición, t. 1, exp. 7; "Proceso contra Bartolomé Quemado por blasfemo", México, 1527, AGNM, Inquisición, t. 1, exp. 9.

"Proceso del Santo Oficio contra Diego de Morales, por blasfemo y hereje", México, 1528, AGNM, Inquisición, v. 1, exp. 11, f. 28-44; "Proceso contra Diego de Morales por blasfemo", México, 1524-1525, AGNM, Inquisición, v. 1, f. 93-134.

"Proceso del Santo Oficio contra Gonzalo Gómez, por palabras malsonantes", México, 1536, AGNM, Inquisición, vol. 2, exp. 2, $77 \mathrm{ff}$. numeradas y $54 \mathrm{ff}$. sin numerar.

SÁNCHEZ Ruiz, Javier S.

La limpieza de sangre en la Nueva España, el funcionariado del Santo Oficio de la Inquisición, siglo XVI

Tesis de Maestría, UNAM, 1990.

SUÁREZ, Luis

La expulsión de los judios de España

MAPFRE, Madrid, 1992.

"Testificación de Baltasar Araujo contra Luis Franco Rodriguez" en Manuel Tejado Fernández, Aspectos de la vida social en Cartagena de Indias durante el seiscientos

Escuela de Estudios hispanoamericanos de Sevilla, Sevilla, 1954.

"Testimonio de Pedro Vázquez de Vergara, natural de Sevilla, de edad de más de setenta años", en "Diligencias sobre los sambenitos antiguos y renovación de ellos..."

México, 1574, AGNM, Inquisición, v. 77, exp. 35.

"Testimonio de fray Vicente de las Casas", En "Diligencias sobre los sambenitos antiguos y renovación de ellos...", v. 77, exp. 35.

"Testimonio de Pedro Vázquez de Vergara"; "Testimonio de Diego de Valadéz", conquistador de esta tierra de más de ochenta años; "Testimonio de Bartolomé González" natural de Mari-Alva, Portugal, en Diligencias sobre los sambenitos antiguos y renovación de ellos..., v. 77, exp. 35 .

\section{TORO, Alfonso}

La familia Carvajal, estudio histórico sobre los judios y la Inquisición de la Nueva España en el siglo XVI, basado en documentos originales y en su mayor parte inéditos, que se conservan en el Archivo General de la Nación de la Ciudad de México

México, Patria, 1944, Tomo I.

UCHMANY, Eva A.

"De algunos cristianos nuevos en la conquista y colonización de la Nueva España"

En Estudios de Historia Novohispana

Instituto de lnvestigaciones Históricas UNAM, México, 1985, vol. 8. pp. 205-318. 
UCHMANY Eva A.

"Identidad y asimilación: cristianos nuevos y criptojudios en la Nueva España "

En Encuentro y Alteridad: vida y cultura judía en América Latina

México, FCE, 1999, pp. 73-84.

UCHMANY, Eva A.

La vida entre el judaismo y el cristianismo en la Nueva España, 1580-1606

FCE y Archivo General de la Nación, México, 1992, reimpresión 1994.

UCHMANY, Eva A.

"Los judios de Cochin"

En Papeles de India

Consejo Indio de Relaciones Culturales, 1993, vol. XXII, núm. 4, pp. 52-75.

UCHMANY, Eva A.

"Simón Váez de Sevilla"

En Estudios de Historia Novohispana

Vol. 9 No 8, Instituto de Investigaciones Históricas, UNAM, México, 1987.

UCHMANY, Eva A.

"Simón Vaez Sevilla"

En Michael the Diaspora Research Institute, Tel Aviv University...

1983, vol 8 p. 145.

UCHMANY, Eva A.

"The Participation of New Christians and Crypto-Jews in the Conquest, Colonization and Trade of Spanish America, 1521-1660".

En The Jews and the Expansion of Europe to the West, 1450-1800

edited by Paolo Bernardini \& Norman Fiering, The John Carter Brown Library \& Berghahn Books, New York-Oxford, 2001, pp. 186-202. 